\title{
Power and Position in the World City System
}

\section{Citation}

Alderson, Arthur S. and Jason Beckfield. 2004. Power and position in the world city system. American Journal of Sociology 109, no. 4: 811-851.

\section{Published Version}

http://dx.doi.org/10.1086/378930

\section{Permanent link}

http://nrs.harvard.edu/urn-3:HUL.InstRepos:3203614

\section{Terms of Use}

This article was downloaded from Harvard University's DASH repository, and is made available under the terms and conditions applicable to Other Posted Material, as set forth at http:// nrs.harvard.edu/urn-3:HUL.InstRepos:dash.current.terms-of-use\#LAA

\section{Share Your Story}

The Harvard community has made this article openly available.

Please share how this access benefits you. Submit a story.

\section{Accessibility}




\title{
Power and Position in the World City System ${ }^{1}$
}

\author{
Arthur S. Alderson and Jason Beckfield \\ Indiana University
}

\begin{abstract}
Globalization has renewed interest in the place and role of cities in the international system. Recent literature proposes that the fate of cities (and their residents) has become increasingly tied to their position in international flows of investment and trade. Data on the branch locations of the world's 500 largest multinational enterprises in 2000 are subjected to two broad types of network analytic techniques in order to analyze the "world city system." First, 3,692 cities are analyzed in terms of three measures of point centrality. Second, blockmodeling techniques are employed to generalize further about the positions and roles played by cities in the system. These techniques are used to trace out the structure of the world city system, locate cities in the context of a global urban hierarchy, and explore the degree to which this diverges from a simple one-to-one matching of cities onto nation-states in the world system.
\end{abstract}

The phenomenon of globalization has renewed interest in thinking about cities as loci of action in the world system. Recent literature proposes that cities have become increasingly decoupled from local (i.e., regional or national) political geography as the salience of their position in international networks of investment and trade has grown (Friedmann 1986; Knox and Taylor 1995; Sassen 2001). Globalization is argued to be gen-

\footnotetext{
${ }^{1}$ Early versions of this paper were presented at the Social Science History Association annual meeting in St. Louis, October 2002; the American Sociological Association annual meeting in Anaheim, Calif., August 2001; and the workshop "Global Processes and Inequality" organized by the Swedish Council for Planning and Coordination of Research in cooperation with the Swedish Council for Social Research and the Swedish Collegium for Advanced Study in the Social Sciences, Stockholm, October 2000. We thank Michael McKenna, Jim Moody, Chris Chase-Dunn, Tom Gieryn, Scott Long, and Doug White for their comments and assistance. This research was supported by a grant to the first author from the World Society Foundation. Direct all correspondence to Arthur S. Alderson, Department of Sociology, Indiana University, Ballantine Hall 744, Bloomington, Indiana 47405. E-mail: aralders@indiana.edu

(C) 2004 by The University of Chicago. All rights reserved. 0002-9602/2004/10904-0001\$10.00
} 
erating a new geography of centrality and marginality that cuts across the old core/periphery, North/South, and East/West divides in the world system (Sassen 1994, p. 4). In particular, developments of the past few decades are seen as producing a new global hierarchy of cities, at the apex of which are located what have variously been referred to as "world cities" (Friedmann 1986) or "global cities" (Sassen 2001). Such cities constitute the key nodes or command points that exercise power over other cities in a system of cities and, thus, the world economy.

To date, research on world cities and on the structure of the larger world city system has tended toward the impressionistic. In large part, this is attributable to the paucity of data appropriate to a rigorous exploration of the structure of the world city system (Smith and Timberlake 1995a; Taylor, Walker, and Beaverstock 2002). For Short et al. (1996), this state of affairs constitutes the "dirty little secret" of world city research: "Few of the many papers on the global urban system draw upon original data; common hypotheses are repeated rather than tested and most draw upon the assumptions of previous papers. The dominance of London, New York, and Tokyo, for example, is more often asserted than demonstrated" (p. 668). Moreover, when data are assembled with the aim of locating individual cities in a global urban hierarchy, they typically consist of information such as counts of corporate headquarters or banks, rankings of cities in terms of population or air passenger traffic, or the location of stock markets, Olympic Games, or even Rolling Stones concerts (Short et al. 1996). While such data are in some instances the best available and can yield real insights (e.g., Chase-Dunn 1985; Chase-Dunn and Manning 1999), they are less than ideal. For instance, researchers utilizing counts of corporate headquarters to identify and rank world cities (e.g., Abbott 1997; Cohen 1981; Godfrey and Zhou 1999; Lyons and Salmon 1995; Meijer 1993) must simply assume that such attributional data reflect the character of relations with other cities in the world city system (Smith and Timberlake 1993, p. 197). Researchers, in other words, must assume what they set out to establish: cities are situated in a "system," and some cities-as a result of the position that they occupy in this system-are better situated than others.

One way out of this trap is to build on the strong affinity between the literature on world cities and social network analysis, as Smith and Timberlake have repeatedly noted $(1993,1995 a, 1995 b, 2002)$. As conceptualized in the literature, the power of world cities is inherently relational: cities do not have power in and of themselves; they have power to the extent that they function as command points and centers of planning and thus establish the framework in which other cities operate in the world economy. Similarly, social network analysts suggest that power is best viewed as a consequence of patterns of social relations that generate op- 
portunities and constraints: some actors are favored because they occupy positions that are more favorable than others (Granovetter 1973; Padgett and Ansell 1993; Guiffre 1999). Moreover, network analysts have developed a set of tools that enable those interested in pursuing the world city hypothesis to assess (1) the degree of power wielded by individual cities and (2) the positions of and roles played by different types of cities within the world city system.

Smith and Timberlake (1993, p. 197) characterize this potentially happy mating of theory and method as a "perfect marriage." Unfortunately, few researchers have pursued this union. The key exceptions include David Meyer's (1986) exploration of the dominance of core financial centers (e.g., London, New York, and Tokyo) over South American cities through the medium of international bank offices and Smith and Timberlake's (1995b, 2001, 2002; see also Shin and Timberlake 2000) own pioneering work on air travel among Friedmann's (1986) world cities. ${ }^{2}$ In this article we take up Smith and Timberlake's call for more network-oriented analysis and take another step toward mapping the contemporary world city system.

Our approach differs from Meyer's and Smith and Timberlake's in that we focus on what we view as a key relation linking cities into a world system of cities: that between multinational enterprises (MNEs) and their subsidiaries. ${ }^{3}$ Our data consist of information on the headquarter and branch locations of the world's 500 largest multinational firms in 2000. The data are coded as directional (i.e., distinguishing between senders and receivers) and valued (i.e., allowing multiple ties between cities). This produces a matrix linking 3,692 cities across the globe. In this article, we assess the power of world cities in light of three measures of point centrality (namely, outdegree, closeness, and betweenness). As the world city hypothesis suggests that choices received are important, we also assess the prestige of world cities as the indegree of each city. Having established a ranking of world cities in terms of network centrality, we then employ blockmodeling techniques to assess the regular equivalence between cities. Blockmodeling techniques enable us to abstract from information about individual cities and generalize about the nature of relations between

\footnotetext{
${ }^{2}$ In his admirable work on U.S. cities, Christopher Ross $(1987,1992)$ has done similar research that joins network analysis to the traditional human-ecological concern with metropolitan dominance (e.g., Duncan et al. 1960; Hawley 1950).

${ }^{3}$ Smith and Timberlake's (1995a, p. 86) typology of intercity linkages identifies 12 families of relations. While all these relations could be usefully explored, the literature on world cities typically identifies the multinational enterprise as a central agent in the generation of the world city system. Nonetheless, it bears emphasizing that there are important cultural, social, and political dimensions to "world city-ness," and the question of the degree to which they are isomorphic to the economic remains an open one.
} 


\section{American Journal of Sociology}

positions in the world city system and the roles played by different types of cities in that system.

The questions that we address in this paper are concrete. First, while numerous rankings of world cities have been proposed, few have utilized the sorts of relational data necessary to firmly establish such rankings empirically. Thus one aim is simply to determine which cities are in fact central to the MNE-generated city system. Second, having established a ranking of world cities in terms of network centrality, we then examine precisely what sort of "system" these cities form. Is it one composed of cohesive subgroups, bounded, perhaps, by region along the lines of regional trading blocks? Is it a core/periphery system? A simple hierarchy? And what roles are played by different types of cities within this system? Finally, if globalization is indeed generating a new geography of centrality and marginality, this should be reflected in slippage between the map of the world city system and established maps of the world system (e.g., Snyder and Kick 1979; Bollen 1983; Nemeth and Smith 1985; Smith and White 1992). We thus explore the degree to which the power and position of cities in the world city system deviate from a one-to-one matching of cities onto nation-states in the world system.

\section{WORLD CITY HYPOTHESES}

Three decades ago, Stephen Hymer (1972) was assigned the task of producing an essay that would look forward to the turn of the 21 st century. While Hymer is primarily known for his influential work on the multinational enterprise, the paper that he produced is remarkable for the degree to which it anticipates contemporary thinking on the implications of globalization for processes of urbanization. ${ }^{4}$ Extrapolating from trends in the organization of business since the Industrial Revolution, Hymer speculated on what increasing "multinationalization" of the world economy would mean for cities:

[It would] tend to produce a hierarchical division of labor between geographical regions corresponding to the vertical division of labor within the firm. It would tend to centralize high-level decision-making occupations in a few key cities in the advanced countries, surrounded by a number of regional sub-capitals, and confine the rest of the world to lower levels of

\footnotetext{
${ }^{4}$ As noted below, most contemporary research on the world city system takes its lead from Friedmann, who appears to have been unaware of Hymer's work. He credits Castells (1972) and Harvey (1973) with initiating the change in thinking on cities that his own work has advanced and suggests that it was not until the 1980s that "the study of cities [was] directly connected to the world economy" (Friedmann 1986, p. 69).
} 
activity and income, i.e., to the status of towns and villages in the new Imperial system. Income, status, authority, and consumption patterns would radiate out from these centers along a declining curve, and the existing pattern of inequality and dependency would be perpetuated. The pattern would be complex, just as the structure of the corporation is complex, but the basic relationship between different countries would be one of superior and subordinate, head office and branch plant. (Hymer 1972, p. 114)

Joining location theory to Chandler and Redlich's (1961) classic distinction of three levels of management, Hymer (1972) predicted that the structure of the world city system would come to reflect the structure of the modern multinational firm. With increasing internationalization, the activities associated with the day-to-day operations of the firm will spread across the globe. One result would be the diffusion of industrialization to developing countries and the creation of new centers of production outside the highly industrialized core of the world economy. "Midlevel" activities associated primarily with the coordination of managers at the first level will tend to be more geographically concentrated. As their demands are similar (e.g., the need for white-collar labor, communication, and information), such activities will tend to cluster across industries in the same midlevel cities. Activities at the highest level, those involving goal setting and planning, will grow even more concentrated, driven by the need for face-to-face interaction at the highest levels of decision making and the need to be near capital markets, government, and media.

To the extent that this correspondence between the centralization of control within the firm and the world economy grows, geographical specialization will come to reflect the hierarchy of corporate decision making. By the end of the 20th century, Hymer (1972) thought that power in the world economy would become even more concentrated in the hands of multinationals sited in a small number of cities located in core countries and thus foresaw the emergence of a world city system dominated by such traditional powers as New York, London, Paris, and Tokyo. ${ }^{5}$ The structure of income and consumption would likewise come to reflect the structure of status and authority: The "best" jobs would concentrate in or near the major centers, which would transform centers of planning into centers of product innovation and high-status consumption as well. In contrast to some later thinking on globalization and the city, the idea that the consolidation of the "regime of multinational corporations" might create opportunities for upward mobility within the urban hierarchy for previously underdeveloped regions is rejected. Instead, globalization would likely reperipheralize the underdeveloped world—albeit within a

${ }^{5}$ Hymer (1972, p. 124) also offers that Moscow and "perhaps" Beijing would attain the status of world city by the year 2000 . 


\section{American Journal of Sociology}

modified framework-as indigenous centers of planning and control, along with former centers of extraction and colonial/neocolonial administration, are transformed into "branch plant" cities. While alteration of the global urban hierarchy is likely (e.g., the emergence of new centers of production in the South and the simultaneous decline of old centers of production in the North), Hymer predicted that the map of the world city system by century's end would match rather closely established maps of the world system.

While Hymer's (1972) essay has been widely cited, most contemporary research on the world city system takes its lead from John Friedmann (1986), whose statement of the world city hypothesis consists of a series of generalizations regarding urbanization in the context of globalization:

1. The form and extent of a city's integration with the world economy, and the functions assigned to the city in the new spatial division of labour, will be decisive for any structural changes occurring within it.

2. Key cities throughout the world are used by global capital as "basing points" in the spatial organization and articulation of production and markets. The resulting linkages make it possible to arrange world cities into a complex spatial hierarchy.

3. The global control functions of world cities are directly reflected in the structure and dynamics of their production sectors and employment.

4. World cities are major sites for the concentration and accumulation of international capital.

5. World cities are points of destination for large numbers of both domestic and/or international migrants.

6. World city formation brings into focus the major contradictions of industrial capitalism-among them spatial and class polarization.

7. World city growth generates social costs at rates that tend to exceed the fiscal capacity of the state. ${ }^{6}$

Friedmann's world city hypothesis has been credited with opening up a new way of asking questions about cities, one that situates the city in the context of the development of capitalism rather than the general principles of human ecology (Knox 1996). However, as Friedmann (1995) has stressed, it is more than simply a heuristic. It should also be read as a set of statements about a class of cities with specifiable attributes. First, world cities play a distinct role in the articulation of regional, national, and

${ }^{6}$ These seven items are quoted verbatim from Friedmann's (1986, pp. 70-77) article, where they appear as section headings. 


\section{World City System}

international economies into a global economy: "They serve as the organizing nodes of a global economic system" (p. 25). World cities are first and foremost centers. As centers they have power, linking the fields that they are central to into the world economy. Second, the regional, national, and international fields that are articulated by world cities are, when summed, smaller than the world as a whole. Any number of regions (and populations) around the world may be isolates with respect to the world city system. Third, the boundaries of world cities are not defined by administrative or political criteria, but by patterns of interaction. As such, suburbs and the near hinterland should in many instances be conceptualized as integral parts of the larger urbanized region (Sudjik 1992). Fourth, world cities can be arrayed in a hierarchy on the basis of the economic power that they command. Cities of the first rank are those that serve as the "command and control centers of the global economy" (p. 23). Below these stand cities that articulate the economies of multiple nations into the world economy and, lower still, those that articulate national and subnational (regional) economies. Finally, the world city system generates a social class- "the transnational capitalist class"- that is described as sharing common economic interests, a common culture of cosmopolitanism, and a common ideology of consumerism.

Friedmann's (1995) expectations regarding the morphology of the world city system are thus quite clear. Globalization is generating a new urban hierarchy. The cities that stand at its peak are those that are most central to the flow of "economically relevant variables" (p. 22). Below these stand cities that tie otherwise isolate regions into the world economy. Within this latter group there are gradations of rank that reflect variation in the breadth of the area articulated (i.e., multinational, national, and subnational). Large swaths of the world operate outside of the orbit of the world city system. In sharp contrast to the monism of certain brands of neoMarxian thinking (e.g., dependency and world-systems theory), Friedmann suggests that globalization has excluded a large proportion of the world's population and is rendering the traditional capitalist periphery economically irrelevant. ${ }^{7}$ Where Hymer (1972) saw globalization generating a fairly static urban hierarchy dominated by traditional powers,

\footnotetext{
${ }^{7}$ The world map is one of "a core space articulated by a small number of regional control centers and a fragmented marginalized periphery" (Friedmann 1995, p. 41). Regarding Brazil and Peru, for instance, Friedmann writes that "São Paulo and the affluent metropolitan classes of Brazil do not require the country's disempowered poor either as producers or consumers. In this sense, I would argue, more than 50 per cent of Brazil's population is economically irrelevant and, at worst, constitutes a drain on the economy (welfare, police, prisons). Still, civil order is being preserved in Brazil. This is not Peru's story, however. Lacking a São Paulo, that country of 22 million has been excluded wholesale from the global space of accumulation" (p. 41).
} 


\section{American Journal of Sociology}

Friedmann (1995) characterizes the world city system as a dynamic hierarchy with ranks and entrance criteria that are, in principle, open: To the extent that cities can attract investment and capture more of the command and control functions of the world economy, their status in the urban hierarchy will improve. While there is every expectation that cities such as New York, London, and Tokyo will emerge as cities of the first rank in any empirical analysis, "cities may rise into the ranks of world cities, they may drop from the order, and they may rise or fall in rank" (Friedmann 1995, p. 26). This opens up the possibility of substantial slippage between the map of the contemporary world city system and established maps of the world system. The new urban hierarchy generated by globalization may cut across the traditional core/periphery, North/ South, and East/West divides in the world system. ${ }^{8}$

Saskia Sassen's (2001) version of the world city hypothesis has also had an important influence on empirical research on the world city system (e.g., Beaverstock, Taylor, and Smith 1999; Taylor et al. 2002). Sassen's account stresses the novelty of the "complex duality" presently driving processes of urbanization, that of the "spatially dispersed, yet globally integrated organization of economic activity" (2001, p. 3). While globalization has resulted in the dispersion of many day-to-day secondary sector activities (e.g., the decline of old centers of production in the North), it has not been accompanied by any corresponding decentralization of control. Instead, control has become even more centralized. The fundamental dynamic, Sassen suggests, is that "the more globalized the economy becomes, the higher the agglomeration of central functions in a relatively few sites, that is, the global cities" (p. 5).

While sharing much in common with Hymer (1972) and Friedmann (1986), Sassen's (2001) approach is distinctive for the extent to which it problematizes power in the world city system. The case studies of New York, Tokyo, and London presented in The Global City focus less on the

\footnotetext{
${ }^{8}$ While Friedmann's (1995) image of the world system - that of a densely connected archipelago situated in the blank space of exclusion-stresses the unity of interests of the "transnational capitalist class," other possibilities have been suggested. Research on the formation of blocks in the world economy questions the degree to which the world is moving toward a decentralized multilateral world trading system, suggesting instead that the world economy can be subdivided into quasi-exclusive subgroups or factions-“blocks" (e.g., Junne 1999; Blanton 1999). Research on rising eastern hegemony (e.g., Arrighi 1994; Frank 1998) contends that we are in the midst of an important shift in power in the world system from West to East. While such issues are not typically addressed in research on world cities, examination of the structure of the world city system provides a privileged point of purchase on them.
} 
position of cities in a global network and more on the practice of control. ${ }^{9}$ Where earlier statements of the world city hypothesis largely assumed the production and reproduction of control, Sassen proposes that-in the first instance-it is the emergence of a vast range of specialized producer and financial services that makes the global control exercised by firms possible. Thus, in addition to their traditional roles as centers of trade and banking, world cities "function in four new ways: first, as highly concentrated command points in the organization of the world economy; second, as key locations for finance and for specialized service firms, which have replaced manufacturing as the leading economic sectors; third, as sites of production, including the production of innovations, in these leading industries; and fourth, as markets for the products and innovations produced" (Sassen 2001, pp. 3-4).

Sassen $(2001,1994)$ also stresses that world cities share a similar set of internal conditions. In addition to their distinctive role as centers of control and of finance and producer services, world cities exhibit a similar income and occupational distribution, characterized by sharp and growing polarization. ${ }^{10}$ For the world city system as a whole, Sassen's vision is similar to Friedmann's $(1986,1995)$. The new urban hierarchy generated by globalization cuts across the old divides in the world system. Areas in the developed world once conceptualized as "core" are being peripheralized, as cities such as Detroit, Liverpool, and Nagoya have seen their fortunes decline dramatically. As cities such as São Paulo and Mexico City have begun to emerge as cities of the first rank in the global urban hierarchy, areas once conceptualized as "peripheral" have joined the core. Alongside this new urban hierarchy, Sassen (1994) suggests, there exists a "vast territory" that has been increasingly excluded from the "major economic processes that fuel economic growth in the new global economy" (p. 4). As Friedmann does, Sassen argues that globalization is generating a world system with a fundamentally new and different morphology.

\footnotetext{
${ }^{9}$ As Sassen (2001, p. 6) characterizes her approach in The Global City: "My focus is not on power, but on production: the production of those inputs that constitute the capability for global control and the infrastructure of jobs involved in this production." ${ }^{10}$ Similar suggestions are present in Hymer (1972) and Friedmann (1986). Sassen (2001, 1994) goes beyond both in detailing the implications of the "globalized," "postindustrial" economy of the world city for its residents. While this important aspect of the world city hypothesis could in principle be readily assessed—one could, e.g., relate changes in income distribution and occupational structure to the position of cities in the world city system - research on these sorts of issues has been hobbled by the lack of the sorts of relational data necessary to generate a ranking of cities that stretches across the entire global urban hierarchy. One aim of this article is to derive such a ranking.
} 
American Journal of Sociology

DATA AND METHODS

To explore and assess these statements of the world city hypothesis, one would ideally construct a multirelational network, combining data on economic, political, social, and cultural linkages between cities. Unfortunately, such data are exceedingly scarce. As a first step, then, we have assembled data on what is typically described in the literature on world cities as a key relation linking cities into a world system of cities: that between multinational enterprises and their subsidiaries. Our data consist of information on the headquarter and branch locations of the world's 500 largest multinational firms in the year 2000. Data are drawn from the Directory of Corporate Affiliations (National Register 2000). Of the 500 firms listed as members of Fortune (2000) magazine's "Global 500" in 2000, 446 have full information on headquarter and subsidiary locations in the directory. ${ }^{11}$ For each firm listed in the directory, we coded the location of the firm's headquarters and subsidiaries. The program UCINET 6.0 (Borgatti, Everett, and Freeman 2002) was then used to construct a directional, valued data matrix from this list. There are a total of 3,692 unique cities in the list, resulting in a 3,692 $\times 3,692$ matrix. $^{12}$

Table 1 shows the distribution of the Global 500 across industries, lists the revenue of firms in each industry, and gives the total revenue of all firms. The Global 500 are distributed across more than 50 industries. Many of these industries, and the firms within them, are linked in a valueadded hierarchy. The largest cluster (64 firms) is in banking. The combined revenue of the Global 500 totaled more than U.S. \$12.6 trillion in 2000. This was more than twice $(208 \%)$ the combined gross domestic product of the world's 156 poorest societies and equivalent to more than half $(53 \%)$ the combined gross domestic product of the 24 member nations of the OECD in 2000 (World Bank 2002). The activities of the Global 500 thus account for a notable proportion of total world economic activity.

\footnotetext{
${ }^{11}$ The Global 500 are the world's 500 largest corporations. Of the 54 firms without complete information in the Directory of Corporate Affiliations, 24 had a headquarter entry but listed no subsidiaries, 14 were not listed in the directory, and seven were listed as subsidiaries of other firms in Fortune's Global 500. Also excluded from the data were nine firms with no subsidiaries outside the headquarter city. The firms lacking complete information do not appear to share any particular characteristics (e.g., were not clustered in any particular industry or region).

${ }^{12}$ In cases in which cities are located within the boundaries of a larger metropolitan area, as defined by the U.S. National Geographic Society (1996), we recoded them as the metropolitan area (e.g., Courbevoie was recoded as Paris). Information on locations of suburbs from the National Geographic Society was supplemented with data from online sources (i.e., Cohen 2002; MapQuest, which we viewed in 2002 at http:// www.mapquest.com/maps/city.adp). Joining suburbs to metropolitan areas in this fashion reduced the number of unique cities in our data set from 5,303 to 3,692.
} 
TABLE 1

Distribution of the 2000 Global 500 aCross INDUStries

\begin{tabular}{|c|c|c|}
\hline Industry & $N$ of Firms & $\begin{array}{c}\text { Revenue } \\
\text { (\$U.S. Million) }\end{array}$ \\
\hline Aerospace & 8 & 189,309 \\
\hline Airlines $\ldots .$. & 9 & 127,193 \\
\hline Banks, commercial and savings ...... & 64 & $1,384,355$ \\
\hline Beverages $\ldots \ldots \ldots \ldots \ldots \ldots \ldots$ & 5 & 82,591 \\
\hline Building materials, glass $\ldots \ldots \ldots \ldots \ldots$ & 3 & 47,002 \\
\hline Chemicals $\ldots \ldots \ldots \ldots \ldots \ldots \ldots \ldots$ & 11 & 197,567 \\
\hline Computer services and software ....... & 2 & 38,281 \\
\hline Computers, office equipment $\ldots \ldots \ldots \ldots$ & 9 & 313,800 \\
\hline Diversified financials $\ldots \ldots \ldots \ldots \ldots \ldots$ & 6 & 288,281 \\
\hline Electronics, electrical equipment $\ldots \ldots$. & 22 & 717,824 \\
\hline Energy $\ldots \ldots \ldots \ldots \ldots \ldots \ldots \ldots \ldots \ldots$ & 7 & 162,756 \\
\hline Engineering, construction $\ldots \ldots \ldots \ldots$ & 9 & 156,215 \\
\hline Entertainment $\ldots \ldots \ldots \ldots \ldots \ldots \ldots \ldots$ & 5 & 89,093 \\
\hline Food $\ldots \ldots \ldots \ldots \ldots \ldots \ldots \ldots \ldots \ldots \ldots \ldots$ & 10 & 215,577 \\
\hline Food services $\ldots \ldots \ldots \ldots \ldots \ldots \ldots$ & 2 & 23,294 \\
\hline Food and drug stores $\ldots \ldots \ldots \ldots \ldots$ & 25 & 552,462 \\
\hline Forest and paper products $\ldots \ldots \ldots \ldots$ & 6 & 89,809 \\
\hline General merchandisers $\ldots \ldots \ldots \ldots \ldots$ & 15 & 471,327 \\
\hline 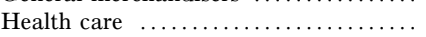 & 7 & 114,298 \\
\hline Industrial and farm equipment ......... & 9 & 180,475 \\
\hline \multicolumn{3}{|l|}{ Insurance: } \\
\hline Life, health (mutual) & 18 & 462,720 \\
\hline Life, health (stock) . . & 18 & 497,128 \\
\hline Property and casualty (mutual) ...... & 3 & 77,791 \\
\hline Property and casualty (stock) $\ldots \ldots \ldots$ & 14 & 410,497 \\
\hline Mail, package, and freight delivery .... & 8 & 192,291 \\
\hline Metal products $\ldots \ldots \ldots \ldots \ldots \ldots \ldots$ & 3 & 31,790 \\
\hline Metals $\ldots \ldots \ldots \ldots \ldots \ldots \ldots \ldots \ldots \ldots$ & 10 & 139,361 \\
\hline Mining, crude oil production .......... & 5 & 76,461 \\
\hline Motor vehicles and parts ............. & 25 & $1,216,482$ \\
\hline Network communications $\ldots \ldots \ldots \ldots$ & 3 & 71,744 \\
\hline Petroleum refining $\ldots \ldots \ldots \ldots \ldots \ldots \ldots$ & 26 & 903,169 \\
\hline Pharmaceuticals .................. & 14 & 245,412 \\
\hline Publishing, printing & 4 & 50,581 \\
\hline Railroads ......................... & 8 & 110,506 \\
\hline Rubber and plastic products $\ldots \ldots \ldots$ & 3 & 46,362 \\
\hline Scientific, photo, control equipment ... & 3 & 42,337 \\
\hline Securities ....................... & 5 & 123,381 \\
\hline Shipping $\ldots \ldots \ldots \ldots \ldots \ldots \ldots \ldots \ldots$ & 2 & 19,831 \\
\hline Soaps, cosmetics .................. & 2 & 49,576 \\
\hline Specialty retailers $\ldots \ldots \ldots \ldots \ldots \ldots$ & 12 & 206,487 \\
\hline Telecommunications $\ldots \ldots \ldots \ldots \ldots \ldots$ & 21 & 617,255 \\
\hline Tobacco ............ & 4 & 111,960 \\
\hline Trading $\ldots \ldots \ldots \ldots \ldots \ldots \ldots \ldots \ldots$ & 20 & 894,204 \\
\hline Utilities, gas and electric $\ldots \ldots \ldots \ldots \ldots$ & 17 & 352,123 \\
\hline Wholesalers $\ldots \ldots \ldots \ldots$. & 11 & 213,800 \\
\hline Miscellaneous* ... & 7 & 91,204 \\
\hline Total $\ldots$ & 500 & $12,695,951$ \\
\hline
\end{tabular}

* Miscellaneous includes staffing, advertising, tourism, construction, building management, and waste management. 
American Journal of Sociology

Power and Prestige in the World City System

We assess the power of world cities in light of three measures of point centrality (i.e., outdegree, closeness, and betweenness). To understand the differences between these measures, it may be useful to consider the two networks illustrated in figure 1. Assume, for instance, that the relation illustrated in figure 1 involves the exchange of resources between cities. Examining the star network, one would conclude that city A occupies a favorable structural position, whereas cities B-G occupy the same, equally unfavorable position. In the circle network, by contrast, all cities appear equally advantaged or disadvantaged. Why is city A advantaged in the star network? Freeman's (1979) now classic treatment of centrality in social networks suggests three distinct reasons.

Outdegree centrality.-City A in the star network is advantaged because it is more active than cities B-G. As such, city A has more alternatives. If city $\mathrm{B}$ refuses an exchange with $\mathrm{A}$, $\mathrm{A}$ can rely on resources from $\mathrm{C}-\mathrm{G}$. By contrast, $\mathrm{B}-\mathrm{G}$ are less active. They are isolated from direct involvement with others in the network and have no alternatives to exchange with A. In this sense, city A is more powerful than cities B-G. In the circle network, by contrast, all cities are equally active and thus equally advantaged or disadvantaged. With directional data, it is often important to distinguish between outdegree (ties sent) and indegree (ties received). With a relation of the sort explored in this paper, the outdegree of each city is a fairly straightforward measure of power or influence: cities that send more ties are cities that have captured more of the control functions of the world economy (i.e., display more "world city-ness" than others). ${ }^{13}$

Closeness centrality.-City A in the star network is advantaged because it is closer to more cities than cities B-G. City A is adjacent to all other cities whereas B-G are two steps from all other cities (except A). Consequently, city A has greater power in the sense that it is more independent than the others (or, alternatively, in the sense that it can avoid being controlled by others). For resources to pass from city B to city E, they must pass through A. In contrast, city A can directly communicate with

${ }^{13}$ The outdegree $C_{D}^{\prime}$ of node (city) $n_{i}$ is simply

$$
C_{D}^{\prime}\left(n_{i}\right)=\frac{x_{i+}}{g-1},
$$

where $x_{i+}$ represents the number of ties sent from city $i$, and $g-1$ is the maximum possible number of ties linking $i$ to $j$. Standardization by $g-1$ typically renders the measure as the proportion of all cities sent ties from city $i$. However, when valued data are employed, the centrality index may be greater than one. For this reason, we report the raw outdegree of each city below. (This formula, and those that follow below are taken verbatim from Wasserman and Faust [1994, p. 199].) 

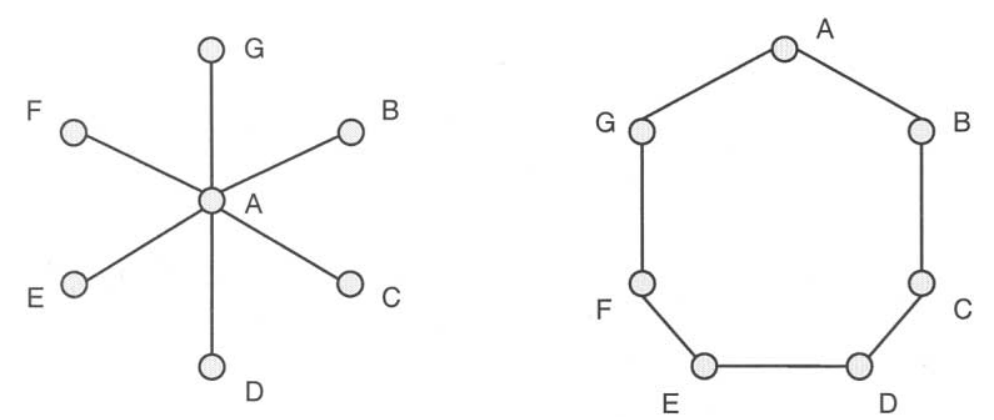

FIG. 1.-Graphs to illustrate centrality measures

B-G. This gives city A in the star network a distinct structural advantage. In the circle network, all actors are equally close and are thus, again, equally advantaged or disadvantaged.

In calculating closeness centrality, we transformed the asymmetric, valued matrix used to estimate outdegree centrality into a symmetric, dichotomous matrix. We did this for combined substantive and methodological reasons. Substantively, the nature of the data argues for treating the matrix as undirected in this instance. To treat the relation between cities as asymmetric would force the unrealistic assumption that a tie sent from city A to B does not serve as a pathway of communication from B to A. Clearly, information flows in both directions through the ties between headquarter and subsidiary cities. Methodologically, the asymmetric matrix used to estimate outdegree centrality is disconnected on both in- and out-closeness (e.g., cities with no in- or outdegree are adjacent to no other cities). This means that closeness centrality cannot properly be estimated. ${ }^{14}$

Betweenness centrality.-Finally, city A in the star network is advantaged because it stands between all the other pairs of actors. It thus has greater power in the sense that it brokers all exchanges. If city B wishes to exchange resources with city $\mathrm{E}$, it must do so through city A. City A

${ }^{14}$ The closeness $C_{C}^{\prime}$ of city $n_{i}$ is (Wasserman and Faust 1994, p. 185)

$$
C_{C}^{\prime}\left(n_{i}\right)=\frac{g-1}{\sum_{j=1}^{g} d\left(n_{i}, n_{j}\right)},
$$

where $d\left(n_{i}, n_{j}\right)$ is the number of lines in the geodesic linking cities $i$ and $j$. Closeness can thus be understood as the inverse average distance between city $i$ and all other cities. Standardization by $g-1$ ensures that closeness equals unity when city $i$ is adjacent to (i.e., one line from) all other cities. The matrix is dichotomized because the closeness algorithm is insensitive to the value of the geodesic linking cities $i$ and $j$ (i.e., city $i$ is considered no more or less distant from city $j$ as the value of the lines connecting them rises or falls). 


\section{American Journal of Sociology}

thus has the power to coordinate action and to withhold or distort information to its advantage. This, mirrored by the fact that city A needs no broker for exchanges with $\mathrm{B}-\mathrm{G}$ in the star network, gives it a distinct structural advantage. In the circle network, each city lies between each other pair of actors, and $\mathrm{A}-\mathrm{G}$ are, again, equally advantaged or disadvantaged.

In calculating betweenness centrality, we again use the symmetric, dichotomous matrix employed to calculate closeness. Our reasoning is identical to that discussed above: treating the relation between cities as asymmetric would force the unrealistic assumption that a tie sent from city $\mathrm{A}$ to $\mathrm{B}$ does not serve as a pathway of communication from B to A. ${ }^{15}$

Indegree centrality. - While the world city hypothesis emphasizes the power of world cities, it also suggests that, in addition to being influential, world cities are prominent or prestigious: they are sought out by other cities, have ties directed to them, and are chosen over others. Put differently, world city-ness involves choices received in addition to choices made. A simple and straightforward measure of a city's prestige is its indegree-the number of ties it receives ${ }^{16}$ Cities that have high indegree are prestigious in precisely the sense discussed above.

\section{The Structure of the World City System}

Having established a ranking of cities in terms of power and prestige, we employ blockmodeling techniques to abstract from information about individual cities and to generalize about ties between positions and the roles played by different sets (blocks) of cities within the world city system. In essence, blockmodeling involves the grouping together of similar cities,

${ }^{15}$ The betweenness $C_{B}^{\prime}$ of each city $n_{i}$ is calculated as (Wasserman and Faust 1994, p. 190)

$$
C_{B}^{\prime}\left(n_{i}\right)=\frac{\sum_{j<k} g_{j k}\left(n_{i}\right) / g_{j k}}{(g-1)(g-2) / 2},
$$

where $g_{j k}\left(n_{i}\right) / g_{j k}$ is the probability that the geodesics $g$ linking cities $j$ and $k$ contain city $i$. The standardization $(g-1)(g-2) / 2$ ensures that $C_{B}\left(n_{i}\right)$ falls between zero (when a given node $n_{i}$ falls on no geodesics) and one (when the $i$ th city falls on all geodesics). ${ }^{16}$ We calculate the prestige $P_{D}^{\prime}$ of city $n_{i}$ as (Wasserman and Faust 1994, p. 203)

$$
P_{D}^{\prime}\left(n_{i}\right)=\frac{x_{+i}}{g-1},
$$

where $x_{+i}$ represents the number of ties received by city $i$, and $g-1$ is the maximum possible number of ties linking $i$ to $j$. As with outdegree centrality, standardization by $g-1$ typically renders the measure as the proportion of all cities that choose city $i$; but with valued data, values greater than one are possible. We thus report the raw indegree of each city below. 
the description of what makes them similar, and the description of what makes them different, as a group, from members of other groups (White, Boorman, and Breiger 1976; Wasserman and Faust 1994).

We use regular equivalence as the criterion for partitioning cities into positions (White and Reitz 1983; White 1984). The regular equivalence criterion dictates that cities be assigned to sets composed of cities that have the same relation to members of other equivalence sets. For example, assume that what is illustrated in figure 2 is, as in our data, a network of cities in which the ties are those between headquarters and subsidiaries, such that the line from city 1 to city 2 indicates that a firm headquartered in city 1 has a subsidiary in city 2 . When the regular equivalence criterion is applied to this network, the maximal regular equivalence partition is one with three equivalence sets or blocks: block 1 , which contains city 1 , block 2, which contains cities 2-4 (equivalent in receiving ties from members of block 1 and sending ties to members of block 3), and block 3 , containing cities 5-9 (equivalent in receiving ties from members of block 2 and not receiving ties from members of block 1 ).

White and Reitz's regular graph equivalence (REGE) algorithm (1985; see also Faust 1988) calculates $\boldsymbol{M}_{i j}^{t+1}$, the degree of regular equivalence for cities $i$ and $j$ at iteration $t+1$, as (Wasserman and Faust 1994, p. 480)

$$
\boldsymbol{M}_{i j}^{t+1}=\frac{\sum_{k=1}^{g} \max _{m=1}^{g} \sum_{r=1}^{R} \boldsymbol{M}_{k m}^{t}\left({ }_{i j r} \boldsymbol{M}_{k m r}^{t}+{ }_{j i r} \boldsymbol{M}_{k m r}^{t}\right)}{\sum_{k=1}^{g} \max _{m}^{*} \sum_{r=1}^{R}\left({ }_{i j r} \operatorname{Max}_{k m r}+{ }_{j i r} \operatorname{Max}_{k m r}\right)} .
$$

The REGE algorithm thus determines how well city $i$ 's ties with city $k$ match the profile of city $j$ 's ties to city $m\left({ }_{i j r} M_{k m r}\right)$, weights this by the regular equivalence of $k$ and $m$ from the previous iteration $\left(\boldsymbol{M}_{k m}^{t}\right)$, and then divides this by the maximum possible value of the numerator. The numerator would attain the maximum value (one) when all of city $i$ 's ties could be matched with city $j$ 's ties and all their alters were regularly equivalent.

\section{World Cities in the World System}

Having established a ranking of cities in terms of their power and prestige in the MNE-generated city system, assigned cities to positions, and generalized about the roles played by different types of cities within that system, we conclude by exploring the degree to which the position of cities in the world city system deviates from a one-to-one matching of cities onto nation-states in the world system. Do powerful and prestigious cities cluster in the core of the world system? Is the "dominant" position within the system likewise monopolized by cities located in the core countries? Or does the contemporary urban hierarchy cut across the core/periphery 


\section{American Journal of Sociology}

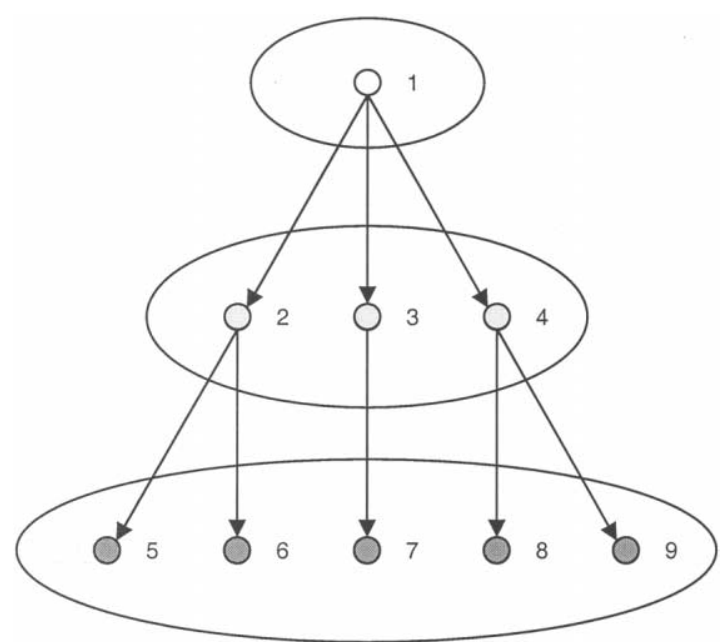

FIG. 2.-Graph to illustrate regular equivalence

divide in the interstate system in the fashion suggested by Friedmann (1986) and Sassen (2001)?

To address these questions, we match each city to its country and assign it to core, peripheral, or semiperipheral status on the basis of Bollen's (1983) revision and update (Bollen and Appold 1993) of the scheme originally presented by Snyder and Kick (1979). ${ }^{17}$ We test for differences by world system position by estimating a series of ordinary least squares (OLS) and logistic regressions that relate standing in the urban hierarchy to location in core, peripheral, or semiperipheral countries. Network data of the sort we have assembled violate a number of standard assumptions of regression analysis (e.g., assumptions of random sampling and of the independence of observations are plainly violated). As such, classical significance tests may not be appropriate. We therefore employ a robust alternative, multiple regression with a "significance test" derived from a

\footnotetext{
${ }^{17}$ Information on world system position was not available in these sources for 28 countries: Angola, Azerbaijan, the Bahamas, Bahrain, Belarus, Belize, BosniaHerzegovina, Brunei, Burkina Faso, Cape Verde, Croatia, Djibouti, Estonia, Iceland, Kazakhstan, Latvia, Lesotho, Lithuania, Macedonia, Mozambique, Qatar, Slovenia, Solomon Islands, Swaziland, Tonga, United Arab Emirates, and Uzbekistan. Eleven of these countries emerged in Eastern Europe after 1989. In these instances, we assign the new nation the status of its predecessor (e.g., the former Soviet Union was coded as semiperipheral in Snyder and Kick [1979], and we therefore code Estonia as semiperipheral). For the remaining 17 cases, we assigned world system position on the basis of the structure of foreign trade (e.g., Burkina Faso shares the profile of other peripheral African countries and is coded as such).
} 


\section{World City System}

permutation test (Good 2000; Borgatti et al. 2002). The procedure that we use first performs a standard OLS or logistic regression. It then randomly permutes the rows of the dependent variable and recalculates the regression. It does this 1,000 times and produces a $P$-value that represents the proportion of random permutations that yield a coefficient as large as that observed. Thus at the conventional .05 level, one would declare a coefficient "significant" if the proportion of coefficients as large was less than .05 . The regressions and permutation tests were carried out using the Stata program (Stata Corporation 2002). All other procedures discussed in this section were carried out using the UCINET program (Borgatti et al. 2002).

\section{RESULTS}

Basic statistics and correlations among the various measures of power and prestige are presented in table 2 . Three findings are worthy of note. First, the summary statistics indicate that the various measures of power and prestige are very highly skewed. The distributions of outdegree and betweenness, for instance, have medians of the lowest possible value. Consequently, we report nonparametric Spearman rank correlation coefficients here and below. ${ }^{18}$ Second, outdegree, closeness, and betweenness are imperfectly correlated. A city's ranking thus varies depending on which of the three senses of power discussed above is stressed. Finally, prestige (as indegree) is positively correlated with the various measures of power. This means that powerful cities are also typically prestigious cities; they are sought out and have ties directed to them. The relation between headquarter and subsidiary cities is thus not exclusively one of metropolis and satellite (e.g., Hymer 1972). There is a fair degree of deference at work in the world city system as well.

\section{Power and Prestige in the World City System}

Outdegree.-Table 3 lists the 50 cities with the largest values on the various measures of power and prestige. ${ }^{19}$ Of the senses of power discussed in the literature on world cities, degree centrality is arguably the most prominent. World cities are variously defined as "headquarter cities" (Hymer 1972 , p. 124), as "basing points in the spatial organization and articulation of production and markets" (Friedmann 1986, p. 71), and as

\footnotetext{
${ }^{18}$ Kendall's $\tau$-b, which corrects for ties in the data, yields substantively identical results. ${ }^{19}$ Information on all 3,692 cities is presented in an appendix, which is available from the authors on request.
} 
American Journal of Sociology

TABLE 2

Spearman Correlation Coefficients and Basic Statistics for Measures of Power And Prestige

\begin{tabular}{lrccr}
\hline \hline & Outdegree & Closeness & Betweenness & Indegree \\
\hline Outdegree ...... & 1.000 & & & \\
Closeness ....... & .360 & 1.000 & & \\
Betweenness ... & .912 & .367 & 1.000 & \\
Indegree ....... & .793 & .518 & .731 & 1.000 \\
Minimum ...... & .00 & 23.75 & .00 & .00 \\
Maximum ...... & $3,639.00$ & 55.51 & 25.65 & $1,425.00$ \\
Mean ......... & 7.82 & 34.21 & .05 & 7.82 \\
Median ........ & .00 & 34.11 & .00 & 1.00 \\
SD ............ & 101.75 & 3.26 & .67 & 46.56 \\
\hline
\end{tabular}

NotE. $-N=3,639$.

"concentrated command points in the organization of the world economy" (Sassen 2001, p. 3). In this sense, outdegree is an unambiguous indicator of world city-ness: Cities that send more ties are cities that have captured more of the control functions of the world economy. As noted above, the distribution of outdegree is highly skewed. The Global 500 are headquartered in just 125 cities in 2000. Consequently, 3,567 of the 3,692 cities in the network send no ties at all (i.e., outdegree $=0$ ). Among the subset of cities that send ties, outdegree remains highly skewed. At one extreme stand cities such as Tokyo, New York, Paris, and London, which send thousands of ties each. At the other stand cities such as Fukuoka (Japan) and Camp Hill (Pennsylvania) that send just a single tie to other cities.

Does the global urban hierarchy that emerges from these relational data differ substantially from the intuitive or attribute-based rankings that have proliferated in recent years in the literature on world cities? ${ }^{20}$ To answer this question, table 4 compares our results with two such rankings. The first is the more or less intuitive ranking proposed by Friedmann (1995). Thirty cities are grouped under four headings that signal the breadth of the area articulated by the city. The second is the inventory of world cities developed by Beaverstock et al. (1999). Consistent with Sassen's (2001) definition of world cities as centers of producer and financial services, Beaverstock et al. rank world cities in terms of their "prime," "major," or "minor" status as global service centers in the realms of accountancy, advertising, banking, and legal services. Cities that score highest in their coding scheme (i.e., London, Paris, New York, and Tokyo) are cities that are prime centers in all four sectors. In total, they identify

${ }^{20}$ See Beaverstock et al. (1999) for a review of the various rankings of world cities that have been proposed and a "citation count" of all cities mentioned in world city research. 


\section{World City System}

and rank 55 cities. Below each ranking, we report the extent of overlap between the proposed list and the top 50 cities on each measure (as reported in table 3).

Not surprisingly, agreement is highest at the apex of the global urban hierarchy. Friedmann, Sassen, and Hymer argue that cities such as London, New York, and Tokyo sit at the top of the world city system, and these cities display, by far, the largest outdegree. There are, however, at least two surprises at the top. First, Tokyo is far more important than one would assume on the basis of the literature. While described as a city of the first rank, Tokyo is typically viewed as being eclipsed by London and New York in power. By the end of the 20th century, this was clearly not the case. Tokyo's outdegree is considerably larger than that of London and New York. According to the results for the two other measures of power, Tokyo also surpasses London and New York in terms of closeness and betweenness. Second, despite being characterized by Friedmann (1995) as only a "national" city, Paris emerges as a city of the first rank by the turn of the century. It eclipses London in terms of outdegree and also surpasses Tokyo, London, and New York in terms of closeness and betweenness. ${ }^{21}$

Below the top, there are notable discrepancies between the ranking of cities on outdegree in table 3 and the lists of world cities presented in table 4. For the Friedmann scheme, $67 \%$ of the 30 cities that he identifies appear among the 50 cities with the largest outdegree. For the Beaverstock et al. inventory, just $46 \%$ of their 55 cities appear. It is interesting to note (1) the cities that are identified as powerful by our network analysis that are overlooked by Friedmann and Beaverstock et al. and (2) the cities identified as powerful by these authors that do not emerge as such in our analysis. In the case of the former, it is noteworthy that St. Louis, Basel, and Philadelphia appear among the top 25 cities on outdegree yet receive no mention in table 4 . In the case of the latter, it is striking that cities such as Miami, Singapore, Mexico City, São Paulo, and Sydney do not appear among the top 50 cities on outdegree. ${ }^{22}$

\footnotetext{
${ }^{21}$ It is unclear to what extent our findings regarding Tokyo and Paris may be biased by the type of data we employ. In this regard, it is worth noting that Smith and Timberlake (2001) and Shin and Timberlake (2000) report very similar results regarding the status of Paris in their network analysis of air travel among cities, whereas Tokyo appears less prominent than in our data.

${ }^{22}$ Perhaps the most notable omissions from table 3 are Miami and Singapore. Both are typically given a prominent place in intuitive and attribute-based rankings of world cities. Singapore is mentioned in nine of the 15 studies reviewed by Beaverstock et al. (1999), and Miami is mentioned in seven. It is important to note that such cities may in fact be central to regional city systems (i.e., Asian and Latin American) while, at the same time, being notably less prominent in the world city system (e.g., Shin and
} 
TABLE 3

Ranking of Cities on Measures of Power and Prestige

\begin{tabular}{|c|c|c|c|c|c|c|c|c|}
\hline Rank & Outdegree & Value & Closeness & Value & Betweenness & Value & Indegree & Value \\
\hline $1 \ldots \ldots$ & Tokyo & 3,639 & Paris & 55.51 & Paris & 25.65 & New York & 1,425 \\
\hline $2 \ldots \ldots$ & New York & 2,601 & Tokyo & 53.59 & Tokyo & 15.04 & London & 1,086 \\
\hline $3 \ldots \ldots$ & Paris & 2,535 & London & 53.47 & Düsseldorf & 13.61 & Paris & 944 \\
\hline $4 \ldots \ldots$ & London & 1,955 & New York & 52.87 & London & 13.31 & Tokyo & 762 \\
\hline $5 \ldots \ldots$ & Düsseldorf & 1,278 & San Francisco & 51.47 & New York & 10.01 & Los Angeles & 538 \\
\hline $6 \ldots \ldots$ & Amsterdam & 897 & Düsseldorf & 50.90 & San Francisco & 7.29 & Chicago & 477 \\
\hline $7 \ldots \ldots$ & Zurich & 893 & Amsterdam & 50.84 & Munich & 4.89 & Brussels & 452 \\
\hline $8 \ldots \ldots$ & Munich & 881 & Munich & 50.05 & Oslo & 4.60 & Amsterdam & 435 \\
\hline $9 \ldots \ldots$ & Osaka & 787 & Chicago & 49.55 & Vevey & 4.46 & Singapore & 434 \\
\hline $10 \ldots$ & San Francisco & 755 & Stockholm & 49.43 & Zurich & 4.32 & Hong Kong & 424 \\
\hline $11 \ldots$ & Frankfurt & 515 & Toronto & 49.06 & Beijing & 4.23 & Toronto & 412 \\
\hline $12 \ldots$ & Vevey & 491 & Zurich & 48.97 & Atlanta & 4.22 & Madrid & 338 \\
\hline $13 \ldots$ & Chicago & 455 & Los Angeles & 48.62 & Amsterdam & 4.09 & Philadelphia & 334 \\
\hline $14 \ldots$ & Stockholm & 427 & Madrid & 48.58 & Stockholm & 3.99 & Milan & 322 \\
\hline $15 \ldots$ & Dallas & 413 & Dallas & 48.46 & Osaka & 3.98 & San Francisco & 321 \\
\hline $16 \ldots$ & Detroit & 359 & Houston & 48.38 & Saint Louis & 2.95 & Mexico City & 280 \\
\hline $17 \ldots$ & Utrecht & 336 & Detroit & 48.28 & Detroit & 2.71 & Sydney & 262 \\
\hline $18 \ldots$ & Toronto & 324 & Singapore & 48.26 & Melbourne & 2.61 & São Paulo & 260 \\
\hline $19 \ldots$ & Saint Louis & 315 & Brussels & 48.19 & Dallas & 2.49 & Dallas & 252 \\
\hline $20 \ldots$ & Basel & 304 & Seoul & 48.18 & Omaha & 2.33 & Munich & 250 \\
\hline $21 \ldots$ & Philadelphia & 299 & Osaka & 48.15 & Chicago & 2.32 & Detroit & 243 \\
\hline $22 \ldots$ & Atlanta & 285 & Atlanta & 48.08 & Basel & 2.19 & Houston & 235 \\
\hline $23 \ldots$ & Oslo & 283 & Saint Louis & 48.02 & Philadelphia & 1.98 & Washington & 227 \\
\hline $24 \ldots$. & Beijing & 273 & Mexico City & 47.87 & Turin & 1.72 & Atlanta & 224 \\
\hline $25 \ldots$ & Hamilton & 250 & Milan & 47.76 & Houston & 1.69 & Bangkok & 212 \\
\hline $26 \ldots$ & Omaha & 245 & Hong Kong & 47.72 & Ludwigshafen & 1.65 & Stockholm & 194 \\
\hline
\end{tabular}




\begin{tabular}{|c|c|c|c|c|c|c|c|c|}
\hline 27 & Houston & 240 & Sydney & 47.62 & Hamilton & 1.57 & Düsseldorf & 193 \\
\hline 28 & Ludwigshafen & 239 & Frankfurt & 47.52 & Frankfurt & 1.48 & Buenos Aires & 190 \\
\hline 29 & Turin & 233 & Basel & 47.48 & Rome & 1.48 & Seoul & 190 \\
\hline 30 & Rome & 225 & Oslo & 47.36 & Helsinki & 1.20 & Frankfurt & 189 \\
\hline 31 & Seoul & 204 & Boston & 47.27 & Göteborg & 1.19 & Jakarta & 182 \\
\hline 32 & Rochester & 200 & Buenos Aires & 47.18 & Stuttgart & 1.16 & Kuala Lumpur & 181 \\
\hline 33 & Trieste & 192 & São Paulo & 47.17 & Pittsburgh & 1.09 & Boston & 178 \\
\hline 34 & Los Angeles & 186 & Melbourne & 47.16 & Minneapolis & 1.08 & Zurich & 174 \\
\hline 35 & Stuttgart & 182 & Philadelphia & 46.95 & Peoria & 1.06 & Vienna & 170 \\
\hline 36 & Espoo & 179 & Caracas & 46.76 & Gerlingen & 1.05 & Beijing & 166 \\
\hline 37 & Seattle & 176 & Seattle & 46.72 & Cleveland & 1.01 & Taipei & 162 \\
\hline 38 & Melbourne & 174 & Bangkok & 46.53 & Rochester & 1.01 & Melbourne & 158 \\
\hline 39 & Göteborg & 173 & Kuala Lumpur & 46.51 & Wolfsburg & 1.01 & Osaka & 149 \\
\hline 40 & Hartford & 168 & Minneapolis & 46.50 & Toronto & 1.01 & Barcelona & 148 \\
\hline 41 & Charlotte & 155 & Beijing & 46.49 & Midland & .97 & Hamburg & 147 \\
\hline 42 & Minneapolis & 155 & Helsinki & 46.47 & Arnhem & .97 & Manila & 144 \\
\hline 43 & Bonn & 153 & Rome & 46.43 & Providence & .95 & Dublin & 143 \\
\hline 44 & Boston & 146 & Vienna & 46.42 & Hartford & .93 & Copenhagen & 134 \\
\hline 45 & Madrid & 140 & Cleveland & 46.31 & Moscow & .92 & Caracas & 133 \\
\hline 46 & Wolfsburg & 134 & Moscow & 46.25 & Utrecht & .90 & Rio de Janeiro & 132 \\
\hline 47 & Cincinnati & 132 & Lisbon & 46.20 & Boston & .88 & Lisbon & 131 \\
\hline 48 & Peoria & 132 & Santiago & 46.17 & Luxembourg & .87 & Luxembourg & 128 \\
\hline 49 & Helsinki & 113 & Turin & 46.13 & Seoul & .87 & Miami & 126 \\
\hline 50 & Montreal & 109 & Copenhagen & 46.08 & Hamburg & .87 & Seattle & 126 \\
\hline
\end{tabular}


TABLE 4

RANKINGS OF WORLD CitIES

\begin{tabular}{|c|c|c|}
\hline & Friedmann (1995) & Beaverstock et al. (1999) \\
\hline & $\begin{array}{l}\text { Global financial articulations: } \\
\text { London, New York, Tokyo }\end{array}$ & $\begin{array}{l}\text { Alpha world cities: } \\
a \text {. London, Paris, New York, Tokyo } \\
b \text {. Chicago, Frankfurt, Hong Kong, Los Angeles, Milan, Singapore }\end{array}$ \\
\hline & $\begin{array}{l}\text { Multinational articulations: } \\
\text { Miami, Los Angeles, Frankfurt, Amsterdam, Singapore }\end{array}$ & $\begin{array}{l}\text { Beta world cities: } \\
\text { a. San Francisco, Sydney, Toronto, Zurich } \\
b \text {. Brussels, Madrid, Mexico City, São Paulo } \\
\text { c. Moscow, Seoul }\end{array}$ \\
\hline & $\begin{array}{l}\text { Important national articulations: } \\
\text { Paris, Zurich, Madrid, Mexico City, São Paulo, Seoul, Sydney }\end{array}$ & $\begin{array}{l}\text { Gamma world eities: } \\
\text { a. Amsterdam, Boston, Caracas, Dallas, Düsseldorf, Geneva, } \\
\text { Houston, Jakarta, Johannesburg, Melborne, Osaka, Prague, San- } \\
\text { tiago, Taipei, Washington } \\
\text { b. Bangkok, Beijing, Rome, Stockholm, Warsaw } \\
\text { c. Atlanta, Barcelona, Berlin, Buenos Aires, Budapest, Copenha- } \\
\text { gen, Hamburg, Istanbul, Kuala Lumpur, Manila, Miami, Minne- } \\
\text { apolis, Montreal, Munich, Shanghai }\end{array}$ \\
\hline & $\begin{array}{l}\text { Subnational/regional articulations: } \\
\text { Osaka, San Francisco, Seattle, Houston, Chicago, Boston, } \\
\text { Vancouver, Toronto, Montreal, Hong Kong, Milan, Lyon, } \\
\text { Barcelona, Munich, Düsseldorf }\end{array}$ & \\
\hline \multicolumn{3}{|l|}{ Overlap with table $3(\%)$ : } \\
\hline Outdegree $\ldots \ldots \ldots \ldots$ & 67 & 46 \\
\hline Closeness $\ldots \ldots \ldots \ldots$ & 83 & 69 \\
\hline Betweenness ........... & 53 & 44 \\
\hline Indegree $\ldots \ldots \ldots \ldots \ldots$ & 90 & 75 \\
\hline
\end{tabular}




\section{World City System}

Closeness.-Outdegree centrality identifies as powerful or influential those cities that are most active and visible (i.e., send the largest number of ties). Closeness centrality, by contrast, identifies as powerful those cities with the shortest paths to others in the network (quantified as the inverse average distance between a given city and all others). As one can note in table 2, power in this sense is only weakly correlated with outdegree. Paris, Tokyo, London, and New York again emerge as the most central cities. Below the top, we find a rather different ranking of world cities. Singapore, Mexico City, São Paulo, and Sydney, absent from the top 50 cities on outdegree, now appear. A number of the world cities located in developing countries identified by Beaverstock et al. emerge as important in the closeness analysis: Buenos Aires, Caracas, Bangkok, Kuala Lumpur, and Beijing. Again, it is interesting to note which cities do not emerge as important from the network analysis. Miami is again absent, as are Vancouver, Montreal, and Lyon. Overall, $83 \%$ of the 30 cities identified by Friedmann appear in table 3, whereas $69 \%$ of the 55 cities identified by Beaverstock et al. appear.

Betweenness.-Betweenness centrality identifies as powerful those cities that lie on the paths connecting other cities. Actors with high betweenness have greater power in the sense that they serve as brokers and can control the flow of information through the network. Table 2 reveals that betweenness is highly correlated with outdegree, but only modestly correlated with closeness centrality. As noted above, Paris, by a remarkable margin, is the most "between" of the major world cities. Düsseldorf, the fifth most active and sixth closest city, surpasses both London and New York in betweenness. Interesting results again emerge below the very apex of the global urban hierarchy. Oslo, Vevey (Switzerland), St. Louis, Omaha, Basel, and Philadelphia rank among the top 25 cities on betweenness yet do not appear in table 4. Conversely, Bangkok, Barcelona, Singapore, Mexico City, São Paulo, and Sydney (among others) do not appear in table 3. Overall, 55\% of Friedmann's and 44\% of Beaverstock et al.'s world cities appear among the top 50 cities on betweenness.

Indegree.-A city's indegree can be interpreted as an indicator of its prestige in the sense that cities with high indegree have been chosen over others. The results for indegree suggest that the handful of cities identified as the most powerful are also the most prestigious: New York, London, Paris, and Tokyo display, by far, the highest indegree. This indicates the operation of a fair degree of deference in the world city system. The relation between headquarter and subsidiary cities is not exclusively one of metropolis and satellite - the head office/branch plant structure envi-

Timberlake 2000). The meaning and interpretation of these "discrepancies" are discussed in greater detail below. 
American Journal of Sociology

sioned by Hymer (1972). Instead, less powerful cities actively seek to establish relations with more powerful cities, consistent with Friedmann's (1986) view that cities at the apex of the world city system are used by global capital as "basing points" in the organization and articulation of production and markets and with Sassen's (2001) argument that it is in these key cities that global control is produced.

The degree of overlap with table 4 is greatest for indegree: $90 \%$ of Friedmann's and $75 \%$ of Beaverstock et al.'s cities appear. This suggests that there may be a tendency in the literature on world cities to mistake prestige for power. Consider, for instance, the cities identified as powerful by Friedmann (1986) or Beaverstock et al. (1999) that do not appear in any of the first three columns of table 3. It is hard to resist the conclusion that cities such as Barcelona, Miami, Vancouver, Johannesburg, Jakarta, Prague, and Shanghai are identified as "world cities" over the Omahas, Peorias, and Rochesters of the world-by multiple measures, cities that in fact appear more powerful-owing simply to the greater prestige of the former. Indeed, we find that all of the former (and none of the latter) are among the top 100 cities on indegree. So while cities such as Miami or Shanghai are prestigious, they do not appear to be especially powerful. Of course, it could be that our data on the MNE network miss important cultural, social, or political features of the power of such cities. For instance, it is notable that Miami emerges as a very important city in network analyses of air travel performed by Smith and Timberlake (2001) and Shin and Timberlake (2000). Nonetheless, this apparent tendency to conflate power and prestige suggests that the intuitive and attribute-based rankings that are so common in the literature on world cities should be treated with due caution.

\section{The Structure of the World City System}

What sort of system is this world city system in which power and prestige are so strongly skewed toward a small handful of cities? To answer this question, we employ regular equivalence blockmodeling techniques to generalize about the structure of the world city system. The regular equivalence criterion dictates that cities be assigned to sets composed of cities that have the same relation to members of other equivalence sets. For example, if Susan is the daughter of Jane's sister and Tess is the daughter of Lisa's sister, then regular equivalence dictates that Susan and Tess form a set (which we label "niece") because each has a tie to a member of the set formed by Jane and Lisa (which we label "aunt"). By abstracting from information on the ties of these four individuals using regular equivalence, we identify two positions in the kinship system (and the data are 


\section{World City System}

reduced by $50 \%$ ). In this example, aunts are aunts because they have nieces and nieces are nieces because they have aunts.

The literature on world cities strongly suggests that regular equivalence blockmodeling should reveal a world city system characterized by a simple core/periphery structure. In the core, one will find those cities that play the role of "world city." The cities occupying this position act as "headquarter cities" (Hymer 1972, p. 124), as "basing points in the spatial organization and articulation of production and markets" (Friedmann 1986, p. 71), and as "concentrated command points in the organization of the world economy" (Sassen 2001, p. 3). In the periphery, one will find those cities that play the role of "branch plant cities," cities that are assigned only the day-to-day activities of the world economy. To the extent that such a structure exists, (1) cities within the core/headquarter city category will be adjacent to other headquarter cities, (2) headquarter cities will be adjacent to some peripheral/branch plant cities, and (3) peripheral/branch plant cities will not connect with other branch plant cities. In the language of blockmodeling, the core of the world city system will be a one-block, the core/periphery region a partial one-block, and the periphery/periphery region a zero-block-a classic core/periphery structure (Borgatti and Everett 1999).

In table 5, we list 34 blocks that result from applying the regular equivalence criterion to the MNE-generated city network. ${ }^{23}$ The results are interesting. For one, we find that the four most active cities from the centrality analysis form a regularly equivalent set; that is, London, New York, Paris, and Tokyo, labeled "L-N-P-T" in table 5, relate to other cities in the network in an equivalent fashion. These four cities send roughly $37 \%$ of the ties that are sent, receive more ties than any other block (about $15 \%$ of all ties), and are highly self-reflexive: nearly $23 \%$ of all the ties that cities in this block send are received by members of this block. The next two most active blocks, "Amsterdam" and "Basel" (labeled after the cities within them that are first in alphabetical order), have a similar profile. Nonetheless, they are different enough in terms of their relations with other blocks to form distinct sets.

In the last column of table 5, we assign each block to a position in the network using the typology of positions suggested by Marsden (1989). The

\footnotetext{
${ }^{23}$ In total, 53 blocks emerge at the $75 \%$ level of regular equivalence. Nineteen of them are singleton blocks (i.e., blocks that contain just one city). For the sake of convenience, we exclude them from the tables, figures, and discussion in this section and focus on the 34 nonsingleton blocks. This does not affect the conclusions. We discuss the results of the $75 \%$ regular equivalence partition because they are substantively meaningful, in addition to representing a manageable reduction. A full regular similarity tree detailing the level at which any two cities are aggregated is available from the authors on request.
} 


\section{American Journal of Sociology}

TABLE 5

Block Characteristics and Positions

\begin{tabular}{|c|c|c|c|c|c|c|}
\hline & Block Name & $g_{k}$ & $\mathrm{Out}_{k} / \mathrm{Out}$ & $\operatorname{In}_{k} / \mathrm{In}$ & Self $_{k} / \mathrm{Out}_{k}$ & Position \\
\hline $1 \ldots$ & L-N-P-T & 4 & 37.18 & 14.61 & 22.83 & Primary \\
\hline $2 \ldots$ & Amsterdam & 11 & 25.98 & 11.04 & 17.47 & Primary \\
\hline $3 \ldots$ & Basel & 27 & 20.49 & 6.87 & 15.15 & Primary \\
\hline $4 \ldots$ & Atlanta & 13 & 6.00 & 13.44 & 28.79 & Primary \\
\hline $5 \ldots$ & Caracas & 16 & 2.31 & 4.59 & 26.28 & Primary \\
\hline $6 \ldots$ & Cologne & 6 & 1.20 & .95 & 12.10 & Primary \\
\hline $7 \ldots$ & Bristol & 2 & .52 & .47 & .67 & Primary \\
\hline $8 \ldots$ & Auckland & 16 & .30 & 8.65 & 53.49 & High-status clique \\
\hline $9 \ldots$ & Athens & 52 & .04 & 8.64 & 27.27 & High-status clique \\
\hline $10 \ldots$ & Bochum & 12 & .01 & .55 & 75.00 & High-status clique \\
\hline $11 \ldots$ & Arnhem & 16 & 4.21 & .37 & 4.85 & Low-status clique \\
\hline $12 \ldots$ & Bartlesville & 7 & .54 & .10 & 15.92 & Low-status clique \\
\hline $13 \ldots$ & Aachen & 79 & .00 & 4.98 & .00 & Snob \\
\hline $14 \ldots$ & Brunswick & 7 & .00 & .40 & .00 & Snob \\
\hline $15 \ldots$ & Evansville & 4 & .00 & .12 & .00 & Snob \\
\hline $16 \ldots$ & Geel & 2 & .00 & .07 & .00 & Snob \\
\hline $17 \ldots$ & Genoa & 5 & .00 & .33 & .00 & Snob \\
\hline $18 \ldots$ & Aalten & 818 & .00 & 3.20 & .00 & Isolate \\
\hline $19 \ldots$ & Aarau & 86 & .00 & 1.98 & .00 & Isolate \\
\hline $20 \ldots$ & Aarschot & 394 & .00 & 5.13 & .00 & Isolate \\
\hline $21 \ldots$ & Abu Dhabi & 95 & .00 & 1.89 & .00 & Isolate \\
\hline $22 \ldots$ & Adrian & 182 & .00 & .75 & .00 & Isolate \\
\hline $23 \ldots$ & Akita & 28 & .00 & .26 & .00 & Isolate \\
\hline $24 \ldots$ & Ålborg & 1,493 & .00 & 7.25 & .00 & Isolate \\
\hline $25 \ldots$ & Altdorf & 136 & .00 & .52 & .00 & Isolate \\
\hline $26 \ldots$ & Amarillo & 80 & .00 & .84 & .00 & Isolate \\
\hline $27 \ldots$ & Anderson & 3 & .00 & .02 & .00 & Isolate \\
\hline $28 \ldots$ & Bauru & 17 & .00 & .20 & .00 & Isolate \\
\hline $29 \ldots$ & Billingstad & 11 & .00 & .16 & .00 & Isolate \\
\hline $30 \ldots$ & Bissen & 8 & .00 & .06 & .00 & Isolate \\
\hline $31 \ldots$ & Brentwood & 23 & .00 & .55 & .00 & Isolate \\
\hline $32 \ldots$ & Cumberland & 6 & .00 & .09 & .00 & Isolate \\
\hline $33 \ldots$ & Faridabad & 5 & .00 & .03 & .00 & Isolate \\
\hline $34 \ldots$ & Haugesund & 8 & .00 & .13 & .00 & Isolate \\
\hline
\end{tabular}

Note. $-g_{b}$ is the number of cities in the block, Out $_{b} /$ Out is the ties sent by the block as a percentage of all ties sent, $\mathrm{In}_{k} / \mathrm{In}$ is the ties received by the block as a percentage of all ties received, and Self ${ }_{k} / \mathrm{Out}_{k}$ is the self-ties as a percentage of ties sent by the block.

34 blocks can be assigned to five types of positions. A total of seven blocks occupy what Marsden terms the primary position. Primary blocks are cliques whose members are involved in high levels of relations with outsiders. More specifically, they are blocks with greater than expected ingroup preference (their cliquishness), but also greater than expected out- 
degree and indegree. ${ }^{24}$ Three blocks-Auckland, Athens, and Bochum (Germany) - occupy the position of high-status clique. High-status cliques are highly cliquish (i.e., have high ingroup preference) and have greater than expected indegree and lower than expected outdegree. Cities in these blocks have ties directed to them by the high-status primary blocks, but they do not reciprocate. Instead, they exchange many of their ties among each other. The Arnhem (Netherlands) and Bartlesville (Oklahoma) blocks occupy the position of low-status clique. Like high-status cliques, lowstatus cliques are cliquish but have lower indegree and greater outdegree than expected. In other words, these cities are active among each other but are largely ignored by higher-status blocks in the system.

The next five blocks occupy what Marsden dubs the snob position. Snobs have greater than expected indegree but low outdegree and ingroup preference. Like high-status cliques, snobs are attended to by higher-status blocks, but snobs do not exchange ties with these blocks or among themselves (i.e., they do not form a clique). Finally, as one can note, most cities in the network are in blocks that occupy Marsden's isolate position. The Ålborg (Denmark) block, for instance, which contains 1,493 cities, has lower than expected outdegree, indegree, and ingroup preference. The cities in these blocks are isolated from one another and play a distinctly secondary role in the system. They constitute the periphery of the city system in the sense that all their relations are with members of more powerful blocks.

Table 6 presents the image matrix that results from applying the $\alpha$ density criterion to the block-model density table. ${ }^{25}$ Rows and columns have been permuted in accordance with the activity level of each block in the system. Figure 3 is a graphical representation of this image matrix. The graphing algorithm that we use arranges the blocks in a twodimensional space in a fashion in which attraction is assumed between

\footnotetext{
${ }^{24}$ Marsden (1989) proposes log-linear methods that allow one to assess the strength of such tendencies. While we use his typology of positions, we do not pursue such methods. Instead, we assign blocks to positions on the basis of simply whether or not Out $k$ /Out, $\mathrm{In}_{k} / \mathrm{In}$, and $\mathrm{Self}_{k} / \mathrm{Out}_{k}$ (see table 5) exceed $g_{k} / g$-cities in a block as a percentage of all cities.

${ }^{25}$ Specifically, this means that if intra- or interblock density exceeds the network mean density, that block is assigned a 1 in the image matrix. Otherwise, it is assigned a 0 . The distribution of ties in the network is such (see table 2) that the $\alpha$ density criterion is nearly equivalent to the zero-block or lean fit criterion originally proposed by White et al. (1976) in which 0 is assigned only when there are no intra- or interblock ties. The density table from which the image matrix was constructed is available from the authors on request.
} 
TABLE 6

Image Matrix of World City System

\begin{tabular}{|c|c|c|c|c|c|c|c|c|c|c|c|c|c|c|c|c|}
\hline & 1 & 2 & 3 & 4 & 5 & 6 & 7 & 8 & 9 & 10 & 11 & 12 & 13 & 14 & 15 & 16 \\
\hline 1. L-N-P-T & 1 & 1 & 1 & 1 & 1 & 1 & 1 & 1 & 1 & 1 & 1 & 1 & 1 & 1 & 1 & 1 \\
\hline 2. Basel & 1 & 1 & 1 & 1 & 1 & 1 & 1 & 0 & 1 & 1 & 1 & 1 & 1 & 1 & 0 & 1 \\
\hline 3. Amsterdam & 1 & 1 & 1 & 1 & 1 & 1 & 1 & 1 & 1 & 1 & 1 & 1 & 1 & 1 & 0 & 1 \\
\hline 4. Arnhem & 1 & 1 & 1 & 1 & 1 & 1 & 1 & 1 & 1 & 1 & 1 & 1 & 1 & 1 & 0 & 1 \\
\hline 5. Atlanta & 1 & 1 & 1 & 1 & 1 & 1 & 1 & 0 & 1 & 1 & 1 & 1 & 1 & 1 & 1 & 1 \\
\hline 6. Caracas & 1 & 1 & 1 & 1 & 1 & 1 & 1 & 0 & 1 & 1 & 1 & 0 & 1 & 1 & 0 & 1 \\
\hline 7. Cologne & 1 & 1 & 1 & 1 & 1 & 1 & 1 & 0 & 1 & 1 & 1 & 1 & 1 & 1 & 0 & 0 \\
\hline 8. Bartlesville & 1 & 1 & 1 & 1 & 1 & 1 & 1 & 1 & 1 & 1 & 1 & 0 & 1 & 0 & 1 & 0 \\
\hline 9. Bristol & 1 & 1 & 1 & 1 & 1 & 1 & 0 & 0 & 1 & 1 & 1 & 0 & 1 & 0 & 0 & 0 \\
\hline 10. Auckland & 1 & 1 & 1 & 1 & 1 & 1 & 0 & 0 & 0 & 1 & 1 & 0 & 1 & 0 & 0 & 0 \\
\hline 11. Athens & 1 & 0 & 0 & 0 & 0 & 0 & 1 & 0 & 0 & 0 & 0 & 0 & 0 & 0 & 0 & 0 \\
\hline 12. Bochum & 0 & 0 & 0 & 0 & 0 & 0 & 0 & 0 & 0 & 0 & 0 & 1 & 0 & 0 & 0 & 0 \\
\hline 13. Aachen & 0 & 0 & 0 & 0 & 0 & 0 & 0 & 0 & 0 & 0 & 0 & 0 & 0 & 0 & 0 & 0 \\
\hline 14. Brunswick & 0 & 0 & 0 & 0 & 0 & 0 & 0 & 0 & 0 & 0 & 0 & 0 & 0 & 0 & 0 & 0 \\
\hline 15. Evansville & 0 & 0 & 0 & 0 & 0 & 0 & 0 & 0 & 0 & 0 & 0 & 0 & 0 & 0 & 0 & 0 \\
\hline 16. Geel & 0 & 0 & 0 & 0 & 0 & 0 & 0 & 0 & 0 & 0 & 0 & 0 & 0 & 0 & 0 & 0 \\
\hline 17. Genoa & 0 & 0 & 0 & 0 & 0 & 0 & 0 & 0 & 0 & 0 & 0 & 0 & 0 & 0 & 0 & 0 \\
\hline 18. Aalten & 0 & 0 & 0 & 0 & 0 & 0 & 0 & 0 & 0 & 0 & 0 & 0 & 0 & 0 & 0 & 0 \\
\hline 19. Aarau & 0 & 0 & 0 & 0 & 0 & 0 & 0 & 0 & 0 & 0 & 0 & 0 & 0 & 0 & 0 & 0 \\
\hline 20. Aarschot & 0 & 0 & 0 & 0 & 0 & 0 & 0 & 0 & 0 & 0 & 0 & 0 & 0 & 0 & 0 & 0 \\
\hline 21. Abu Dhabi & 0 & 0 & 0 & 0 & 0 & 0 & 0 & 0 & 0 & 0 & 0 & 0 & 0 & 0 & 0 & 0 \\
\hline 22. Adrian & 0 & 0 & 0 & 0 & 0 & 0 & 0 & 0 & 0 & 0 & 0 & 0 & 0 & 0 & 0 & 0 \\
\hline 23. Akita & 0 & 0 & 0 & 0 & 0 & 0 & 0 & 0 & 0 & 0 & 0 & 0 & 0 & 0 & 0 & 0 \\
\hline 24. Ålborg & 0 & 0 & 0 & 0 & 0 & 0 & 0 & 0 & 0 & 0 & 0 & 0 & 0 & 0 & 0 & 0 \\
\hline 25. Altdorf & 0 & 0 & 0 & 0 & 0 & 0 & 0 & 0 & 0 & 0 & 0 & 0 & 0 & 0 & 0 & 0 \\
\hline 26. Amarillo & 0 & 0 & 0 & 0 & 0 & 0 & 0 & 0 & 0 & 0 & 0 & 0 & 0 & 0 & 0 & 0 \\
\hline 27. Anderson & 0 & 0 & 0 & 0 & 0 & 0 & 0 & 0 & 0 & 0 & 0 & 0 & 0 & 0 & 0 & 0 \\
\hline 28. Bauru & 0 & 0 & 0 & 0 & 0 & 0 & 0 & 0 & 0 & 0 & 0 & 0 & 0 & 0 & 0 & 0 \\
\hline 29. Billingstad & 0 & 0 & 0 & 0 & 0 & 0 & 0 & 0 & 0 & 0 & 0 & 0 & 0 & 0 & 0 & 0 \\
\hline 30. Bissen & 0 & 0 & 0 & 0 & 0 & 0 & 0 & 0 & 0 & 0 & 0 & 0 & 0 & 0 & 0 & 0 \\
\hline 31. Brentwood & 0 & 0 & 0 & 0 & 0 & 0 & 0 & 0 & 0 & 0 & 0 & 0 & 0 & 0 & 0 & 0 \\
\hline 32. Cumberland & & 0 & 0 & 0 & 0 & 0 & 0 & 0 & 0 & 0 & 0 & 0 & 0 & 0 & 0 & 0 \\
\hline 33. Faridabad & 0 & 0 & 0 & 0 & 0 & 0 & 0 & 0 & 0 & 0 & 0 & 0 & 0 & 0 & 0 & 0 \\
\hline 34. Haugesund & 0 & 0 & 0 & 0 & 0 & 0 & 0 & 0 & 0 & 0 & 0 & 0 & 0 & 0 & 0 & 0 \\
\hline
\end{tabular}




\begin{tabular}{|c|c|c|c|c|c|c|c|c|c|c|c|c|c|c|c|c|c|}
\hline 17 & 18 & 19 & 20 & 21 & 22 & 23 & 24 & 25 & 26 & 27 & 28 & 29 & 30 & 31 & 32 & 33 & 34 \\
\hline 1 & 1 & 1 & 1 & 1 & 0 & 1 & 1 & 0 & 1 & 0 & 1 & 1 & 0 & 1 & 1 & 0 & 1 \\
\hline 1 & 0 & 1 & 1 & 1 & 1 & 1 & 1 & 0 & 1 & 0 & 1 & 1 & 1 & 1 & 1 & 1 & 1 \\
\hline 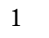 & 1 & 1 & 1 & 1 & 0 & 1 & 1 & 0 & 1 & 0 & 1 & 1 & 0 & 1 & 0 & 1 & 1 \\
\hline 1 & 0 & 1 & 1 & 1 & 1 & 1 & 1 & 0 & 1 & 1 & 0 & 0 & 0 & 1 & 0 & 0 & 1 \\
\hline 1 & 0 & 1 & 1 & 1 & 0 & 1 & 1 & 1 & 0 & 0 & 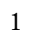 & 0 & 0 & 1 & 0 & 0 & 1 \\
\hline 0 & 0 & 1 & 1 & 1 & 0 & 1 & 0 & 1 & 0 & 0 & 1 & 0 & 1 & 1 & 1 & 1 & 0 \\
\hline 1 & 0 & 1 & 1 & 1 & 0 & 1 & 1 & 1 & 1 & 0 & 0 & 0 & 1 & 1 & 0 & 0 & 0 \\
\hline 1 & 0 & 0 & 1 & 0 & 1 & 1 & 0 & 0 & 1 & 1 & 0 & 0 & 0 & 0 & 0 & 0 & 1 \\
\hline 0 & 0 & 1 & 1 & 0 & 0 & 0 & 1 & 0 & 1 & 0 & 0 & 0 & 0 & 0 & 0 & 0 & 0 \\
\hline 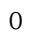 & 0 & 0 & 0 & 0 & 0 & 0 & 0 & 0 & 0 & 0 & 0 & 0 & 0 & 0 & 0 & 0 & 0 \\
\hline 0 & 0 & 0 & 0 & 0 & 0 & 0 & 0 & 0 & 0 & 0 & 0 & 0 & 0 & 0 & 0 & 0 & 0 \\
\hline 0 & 0 & 0 & 0 & 0 & 0 & 0 & 0 & 0 & 0 & 0 & 0 & 0 & 0 & 0 & 0 & 0 & 0 \\
\hline 0 & 0 & 0 & 0 & 0 & 0 & 0 & 0 & 0 & 0 & 0 & 0 & 0 & 0 & 0 & 0 & 0 & 0 \\
\hline 0 & 0 & 0 & 0 & 0 & 0 & 0 & 0 & 0 & 0 & 0 & 0 & 0 & 0 & 0 & 0 & 0 & 0 \\
\hline 0 & 0 & 0 & 0 & 0 & 0 & 0 & 0 & 0 & 0 & 0 & 0 & 0 & 0 & 0 & 0 & 0 & 0 \\
\hline 0 & 0 & 0 & 0 & 0 & 0 & 0 & 0 & 0 & 0 & 0 & 0 & 0 & 0 & 0 & 0 & 0 & 0 \\
\hline 0 & 0 & 0 & 0 & 0 & 0 & 0 & 0 & 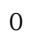 & 0 & 0 & 0 & 0 & 0 & 0 & 0 & 0 & 0 \\
\hline 0 & 0 & 0 & 0 & 0 & 0 & 0 & 0 & 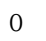 & 0 & 0 & 0 & 0 & 0 & 0 & 0 & 0 & 0 \\
\hline 0 & 0 & 0 & 0 & 0 & 0 & 0 & 0 & 0 & 0 & 0 & 0 & 0 & 0 & 0 & 0 & 0 & 0 \\
\hline 0 & 0 & 0 & 0 & 0 & 0 & 0 & 0 & 0 & 0 & 0 & 0 & 0 & 0 & 0 & 0 & 0 & 0 \\
\hline 0 & 0 & 0 & 0 & 0 & 0 & 0 & 0 & 0 & 0 & 0 & 0 & 0 & 0 & 0 & 0 & 0 & 0 \\
\hline 0 & 0 & 0 & 0 & 0 & 0 & 0 & 0 & 0 & 0 & 0 & 0 & 0 & 0 & 0 & 0 & 0 & 0 \\
\hline 0 & 0 & 0 & 0 & 0 & 0 & 0 & 0 & 0 & 0 & 0 & 0 & 0 & 0 & 0 & 0 & 0 & 0 \\
\hline , & 0 & 0 & 0 & 0 & 0 & 0 & 0 & 0 & 0 & 0 & 0 & 0 & 0 & 0 & 0 & 0 & 0 \\
\hline 0 & 0 & 0 & 0 & 0 & 0 & 0 & 0 & 0 & 0 & 0 & 0 & 0 & 0 & 0 & 0 & 0 & 0 \\
\hline- & 0 & 0 & 0 & 0 & 0 & 0 & 0 & 0 & 0 & 0 & 0 & 0 & 0 & 0 & 0 & 0 & 0 \\
\hline 0 & 0 & 0 & 0 & 0 & 0 & 0 & 0 & 0 & 0 & 0 & 0 & 0 & 0 & 0 & 0 & 0 & 0 \\
\hline 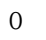 & 0 & 0 & 0 & 0 & 0 & 0 & 0 & 0 & 0 & 0 & 0 & 0 & 0 & 0 & 0 & 0 & 0 \\
\hline 0 & 0 & 0 & 0 & 0 & 0 & 0 & 0 & 0 & 0 & 0 & 0 & 0 & 0 & 0 & 0 & 0 & 0 \\
\hline 0 & 0 & 0 & 0 & 0 & 0 & 0 & 0 & 0 & 0 & 0 & 0 & 0 & 0 & 0 & 0 & 0 & 0 \\
\hline 0 & 0 & 0 & 0 & 0 & 0 & 0 & 0 & 0 & 0 & 0 & 0 & 0 & 0 & 0 & 0 & 0 & 0 \\
\hline 0 & 0 & 0 & 0 & 0 & 0 & 0 & 0 & 0 & 0 & 0 & 0 & 0 & 0 & 0 & 0 & 0 & 0 \\
\hline 0 & 0 & 0 & 0 & 0 & 0 & 0 & 0 & 0 & 0 & 0 & 0 & 0 & 0 & 0 & 0 & 0 & 0 \\
\hline 0 & 0 & 0 & 0 & 0 & 0 & 0 & 0 & 0 & 0 & 0 & 0 & 0 & 0 & 0 & 0 & 0 & 0 \\
\hline
\end{tabular}




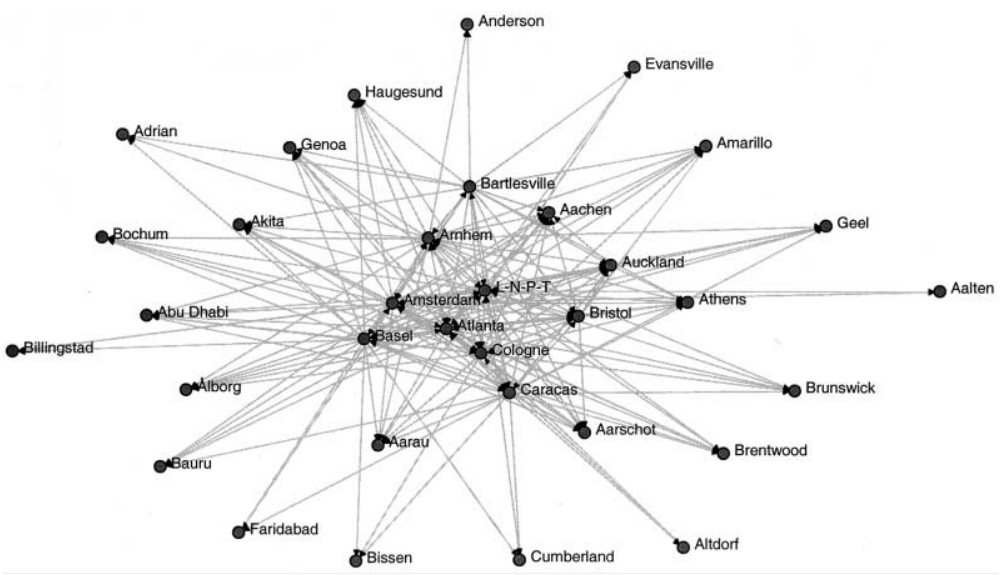

FIG. 3.-Reduced graph of world city system

adjacent blocks and repulsion is assumed between nonadjacent blocks. ${ }^{26}$ Blocks occupying the primary position in the network appear in the center of the graph. The L-N-P-T block falls near the center and is surrounded by the other primary blocks-Amsterdam, Basel, Atlanta, Cologne, Caracas, and Bristol. Auckland and Athens, two of the three high-status cliques, also fall toward the center of the graph, whereas Bochum is notably more distant. The low-status cliques, the Arnhem and Bartlesville blocks, are also closely tied to the center. The snobs-Aachen, Brunswick (Germany), Evansville (Indiana), Geel (Belgium), and Genoa-are, as a group, distributed in the space between the center and periphery. Finally, the 17 isolate blocks occupy a clearly peripheral position, arrayed more or less evenly around the outskirts of the graph.

What sort of system is the world city system? If one compares figures 1 and 3, it is apparent that the world city system bears a strong resemblance to the maximally centralized star, a network in which a single node, $A$, is connected to all other nodes, which, in turn, are disconnected from each other. The difference in figure 3 is that there are multiple $A$ s. In fact, examination of figure 3 and Table 6 indicates that the world city system comes close to approximating an idealized core/periphery structure for a directed relation of this sort (see Borgatti and Everett 1999, esp. fig.

${ }^{26}$ The spring embedder available in the UCINET program NetDraw (Borgatti et al. 2002) was used to assign point locations. Spring embedders treat the graph as a physical system and assume that vertices that are close pull on each other, whereas those that are distant push one another apart. While they differ in the particulars, all such algorithms attempt to find a solution that minimizes the energy of the system (Eades 1984; Fruchterman and Reingold 1991). 


\section{World City System}

3). This is a system in which blocks in the core are adjacent to each other and to some peripheral blocks, whereas blocks in the periphery are disconnected from one another. As one can note from figure 3, blocks in the center of the graph send to each other and also to most other blocks in the system, whereas blocks on the outskirts do not send to each other. Somewhat more formally, if we treat those blocks that occupy Marsden's (1989) primary position as the "core" and all other blocks as a "periphery," we find that the density of the core to core block is much higher than that of the core to periphery block (0.976 vs. 0.651$)$, whereas the density of the periphery to periphery block is quite low (0.047). Thus the core to core block is (nearly) a one-block, the core to periphery block is a partial one-block, and the periphery to periphery block is (nearly) a zero-blocka pattern that Borgatti and Everett (1999) characterize as a defining property of a core/periphery structure. It is also worth noting that the density of the periphery to core region is lower than that of the core to periphery region (0.111 vs. 0.651). This indicates that the blocks occupying the peripheral position in this structure are less sycophantic than they are simply passive (White et al. 1976; Burt 1976). The role that they play looks every bit like that of the "branch plant city" described by Hymer (1972) — cities that enter the city system only by virtue of the fact that they are assigned some day-to-day activity of the world economy. ${ }^{27}$

\section{World Cities in the World System}

What are we to make of the world city system that emerges from the analysis above? Smith and Timberlake (1995a) have suggested that in studying the structure of the world city system, "we stand to learn a great deal more about the nature of the world-system itself" (p. 81). Relations between cities, they propose, undergird the structure of the world system and help to reproduce a global economic order that exhibits a core/periphery structure at the level of the interstate system. As such, we might expect change in the structure of the world city system to precede change

${ }^{27}$ Borgatti and Everett (1999) have developed formal methods for detecting core/periphery structures. If we use their algorithm to fit such a model to Table 6 , we are led to the same substantive conclusions as above. The overall correlation with an ideal core/periphery pattern is very high $(r=0.941)$, the core to core block is (nearly) a oneblock (density $=0.900$ ), the core to periphery block is a partial one-block (density $=$ 0.563 ), and the periphery to periphery block is a zero-block (density $=0.000$ ). The periphery to core block is less dense than the core to periphery block $(0.008$ vs. 0.563$)$. Over the above, the only really notable difference is that the algorithm adds the Auckland, Arnhem, and Bartlesville blocks to the core, in addition to the seven primary blocks identified in table 5 . 


\section{American Journal of Sociology}

in the structure of the world system: Any revision of the global hierarchy is likely to be manifest first in the alteration of relations between cities.

The literature on world cities is rich with claims regarding the effects of the most recent round of globalization on the world system. Friedmann (1986) and Sassen (2001) argue that the restructuring that the world economy has undergone in the past two to three decades has generated a new urban hierarchy that cuts across the traditional divides in the world system. To the extent that this is true, we would expect to observe substantial slippage between the map of the contemporary world city system drawn out above and the map of the world system. Hymer (1972), in contrast, thought that globalization would largely reproduce preexisting crossnational patterns of inequality and dependency. In his view, we should expect the standing of cities in the world city system to match rather closely the position of their nation-states in the world system.

To explore the degree to which a new geography of centrality and marginality may have emerged in recent years, we relate the power and prestige of individual cities and the position that they occupy within the city system to the world system position of the countries in which they are located. As noted above, network data typically violate a number of standard statistical assumptions. We therefore employ a robust alternative to standard regression techniques-regression with "significance tests" derived from a permutation test (Good 2000; Borgatti et al. 2002). Given the highly skewed nature of the measures of network centrality, we ranktransform outdegree, closeness, betweenness, and indegree before performing the regressions. In all models below, we also control for the population of each city. Interestingly, we find that cities in the network that are located in noncore countries are, on average, 10 times larger than those located in core countries. As we show below, there is a strong relationship between the population or raw demographic prominence of a city and its power, prestige, and position in the city system. It is therefore critical that we control for population in testing for effects of world system position; otherwise any effect of world system position would likely be confounded by the large differences in average city size across world system positions. ${ }^{28}$

The results for the measures of power and prestige are presented in table 7 . By both a permutation test and a standard two-tailed test, pop-

\footnotetext{
${ }^{28}$ Cities located in core countries have a mean population of 92,202. Cities located in noncore countries (i.e., in semiperipheral or peripheral countries) have a mean population of 910,452. Clearly, the population threshold beyond which cities enter the city system varies systematically with world system position of the countries in which they are located.
} 
World City System

TABLE 7

Regression Models of Rank-Transformed Measures of Network Centrality: OLS Estimates For 3,023 Cities in 2000

\begin{tabular}{ccccc}
\hline \hline \multicolumn{1}{c}{ Variable } & Outdegree & Closeness & Betweenness & Indegree \\
\hline Semiperiphery $\ldots \ldots \ldots$ & $-303.938 * * *$ & $-339.120 * * *$ & $-369.473 * * *$ & $-604.314 * * *$ \\
& $(-6.33)$ & $(-4.92)$ & $(-4.99)$ & $(-6.98)$ \\
Periphery $\ldots \ldots \ldots \ldots \ldots$ & $-510.030 * * *$ & $-516.284 * * *$ & $-653.627 * * *$ & $-838.403 * * *$ \\
& $(-12.10)$ & $(-8.53)$ & $(-10.06)$ & $(-11.04)$ \\
Population $(\log 10) \ldots$ & $341.124 * * *$ & $636.777 * * *$ & $758.320 * * *$ & $1,087.824 * * *$ \\
& $(19.03)$ & $(24.72)$ & $(27.43)$ & $(33.66)$ \\
Constant $\ldots \ldots \ldots \ldots \ldots$ & $-1,339.92 * * *$ & $-990.444 * * *$ & $-2,925.87 * * *$ & $-3,575.34 * * *$ \\
& $(-16.66)$ & $(8.62)$ & $(-23.72)$ & $(-24.79)$ \\
$R^{2} \ldots \ldots \ldots \ldots \ldots \ldots \ldots$ & .110 & .174 & .210 & .282 \\
\hline
\end{tabular}

Note. - Nos. in parentheses are $t$ scores.

$* P<.05$ (permutation tests).

** $P<.01$.

*** $P<.001$.

${ }^{+} P<.05$ (standard two-tailed tests, when different from permutation tests).

${ }^{++} P<.01$.

${ }^{+++} P<.001$.

ulation (log 10) has a highly significant effect in all four models. ${ }^{29}$ Larger cities tend to rank higher on outdegree, closeness, and betweenness than smaller cities and to rank higher on indegree as well. The position of cities in the global urban hierarchy is thus correlated with their raw demographic prominence (see Chase-Dunn and Manning 1999).

World system position is explicitly ordered (Wallerstein 1974; ChaseDunn and Grimes 1995). The core region of the world economy is more powerful than the semiperipheral region, and the semiperiphery is more powerful than the periphery. Consequently, if the geography of the world system has not been significantly altered in the context of globalization, we would expect that cities located in core countries will, on average, be more powerful than cities located in semiperipheral countries. We would also expect, on average, that semiperipheral cities will be more powerful than peripheral cities. If the contemporary urban hierarchy cuts across the traditional divides in the world system, cities should not be ordered by world system position in this fashion.

The results for outdegree, closeness, and betweenness are consistent with the former set of expectations. In the case of outdegree, the results indicate that cities located in semiperipheral countries are, on average,

${ }^{29}$ The number of cities in the analysis drops to 3,023 owing to missing data for pop-
ulation. Population data are taken from Cohen (2002). The results presented in table
7 are substantively identical when the untransformed measures of power and prestige
are used. The results are also substantively identical when controls for region (i.e.,
Europe, Africa, Asia, Latin American, and North America) are added to the models. 
American Journal of Sociology

TABLE 8

Regression Models of Network Position: Logistic Estimates (Odds Ratios) For 3,003 Cities IN 2000

\begin{tabular}{|c|c|c|c|c|c|}
\hline Variable & Primary & $\begin{array}{l}\text { High-Status } \\
\text { Clique }\end{array}$ & $\begin{array}{l}\text { Low-Status } \\
\text { Clique }\end{array}$ & Snob & Isolate \\
\hline Semiperiphery ....... & $.073 * * *$ & .493 & .225 & $.282 *$ & $6.040 * * *$ \\
\hline & $(-5.54)$ & $(-1.81)$ & $(-1.39)$ & $(-2.99)^{++}$ & $(6.59)$ \\
\hline Periphery ............. & $\begin{array}{l}.012 * * * \\
(-6.75)\end{array}$ & $\begin{array}{r}.509 \\
(-2.13)^{+}\end{array}$ & $\begin{array}{r}.122 \\
(-1.95)\end{array}$ & $\begin{array}{c}.386^{*} \\
(-3.08)^{++}\end{array}$ & $\begin{array}{l}8.129 \text { *** } \\
(9.10)\end{array}$ \\
\hline Population $(\log 10) \ldots$ & $\begin{array}{l}18.689 * * * * \\
(12.33)\end{array}$ & $\begin{array}{l}6.159 \\
(9.74)^{+++}\end{array}$ & $\begin{array}{c}2.187 \\
(2.59)^{+}\end{array}$ & $\begin{array}{l}4.252 * * * \\
(9.02)\end{array}$ & $\begin{array}{c}.096 * * * \\
(-17.73)\end{array}$ \\
\hline Pseudo $R^{2}$ & .347 & .180 & .035 & .109 & .258 \\
\hline
\end{tabular}

NotE. - Nos. in parentheses are $z$ scores.

* $P<.05$ (permutation tests).

** $P<.01$.

**** $P<.001$

${ }^{+} P<.05$ (standard two-tailed tests, when different from permutation tests).

${ }^{++} P<.01$.

${ }^{+++} P<.001$

304 ranks lower on outdegree than cities located in core countries, whereas cities located in peripheral countries are 510 ranks lower. The same pattern is observed for closeness and betweenness: The average rank of cities located in semiperipheral countries is lower than that of core cities, whereas that of cities located in peripheral countries is lower still. The results for indegree, our measure of prestige, are also interesting. We find that cities located in semiperipheral and peripheral countries are, on average, less prestigious than cities located in core countries. ${ }^{30}$ Taken together, the results presented in table 7 would appear more consistent with Hymer's (1972) view of globalization as largely reproducing existing crossnational patterns of inequality and dependency than with Friedmann (1986) and Sassen's (2001) vision of a world city system in the grips of substantial global restructuring. Rather than cutting across the hierarchy of states in the interstate system, the contemporary urban hierarchy appears to map onto it fairly well.

Table 8 presents the results of a series of logistic regressions that relate the position occupied by cities within the city system to the world system position of the countries in which those cities are located. By both a permutation test and a standard two-tailed test, population (log 10) has a significant, positive effect on the odds that a city is a member of a primary block or of a snob block and a negative effect on the odds that

${ }^{30}$ Wald tests indicate that the coefficients of the semiperipheral and peripheral indicator variables are significantly different from one another in all models in table 7 . 
it is a member of an isolate block. ${ }^{31}$ While population has a positive effect on the odds of membership in both high-status and low-status cliques as well, neither coefficient is significant by a permutation test.

The versions of the world city hypothesis under consideration yield clear predictions regarding the composition of the primary and isolate blocks but are silent on the sorts of cities that one might expect to occupy the high-status clique, low-status clique, and snob positions. Hymer's (1972) vision of the world city system is one in which globalization would reperipheralize the underdeveloped world as high-level decision making was further centralized in key cities located in core countries and the rest of the world was consigned to lower levels of activity. To the extent that this is true, one would expect that cities located in noncore countries would be shut out of playing the active, primary role in the system. In addition, one might expect that peripheral cities would have even lower odds of membership in a primary block than semiperipheral cities. At the other end of the spectrum, one would expect that cities located in noncore countries would be disproportionately confined to the passive, isolate position and that peripheral cities would have even greater odds of membership in an isolate block than semiperipheral cities. However, to the extent that a new urban hierarchy has emerged in recent years, a hierarchy that cuts across the traditional divides in the world system, we would not expect the odds of membership in either block to vary systematically with world system position.

Again, the results are more consistent with Hymer's (1972) expectations than with the alternatives. Being located in a semiperipheral country rather than a core country significantly lowers the odds of primary block membership, and being located in a peripheral country lowers the odds even more. On the other hand, being located in a semiperipheral country raises the odds of isolate block membership by a factor of six, whereas cities located in peripheral countries are more than eight times as likely to occupy the isolate position as cities located in core countries. ${ }^{32}$ Thus the odds that a city plays an active or passive role in the world city system are shaped by the world system position of the countries in which they are located.

In sum, the results presented in tables 7 and 8 suggest that the position that nation-states occupy within the world system continues to shape the power, prestige, and position of cities in the world city system. While the $R^{2} \mathrm{~s}$ and pseudo $R^{2} \mathrm{~s}$ reported in the tables are far from 1.0-and thus the

${ }^{31}$ The number of cities in the analysis drops to 3,003 owing to missing data on population and, as discussed above, the exclusion of singleton blocks.

${ }^{32}$ Wald tests indicate that the coefficients of the semiperipheral and peripheral indicator variables are significantly different from one another in the primary and isolate models. 


\section{American Journal of Sociology}

urban hierarchy certainly deviates from a one-to-one matching of cities onto nation-states in the world system-it remains the case that the standing of cities in the world city system is influenced in an important way by the position of their nation-states in the world system.

\section{CONCLUSION}

In this article, we have taken up Smith and Timberlake's (1993, 1995a, $1995 b$, 2002) call for more network-oriented analysis of the world city system. In place of the attributional data typically employed in the literature on world cities, we assembled data on what we view as a key relation linking cities into a world system of cities: that between multinationals and their subsidiaries. Our analysis of these data was motivated by three concrete concerns. First, while numerous rankings of world cities have been proposed, few have used the sort of relational data that the world city hypothesis implies are necessary to establish such rankings empirically. Second, while many have speculated about the structure of the world city system, no one has demonstrated precisely what sort of "system" these cities form; nor has anyone detailed the roles played by different types of cities within that system. Finally, while the literature on world cities is rich with claims regarding the effects of globalization on the structure of the world system, no one has systematically explored the degree to which the position of cities in the world city system might cut across the traditional divides in the world system.

From our analysis of measures of network centrality, we draw a number of conclusions. First, as the various versions of the world city hypothesis predict, we find that power and prestige in the world city system are highly skewed. A small number of cities monopolize power and prestige, and the world city system forms a fairly strong hierarchy. Second, at the apex of this hierarchy, there is considerable agreement between our results and the intuitive and attribute-based rankings that have recently proliferated in the literature on world cities. Cities such as New York, London, and Tokyo are typically identified as the most powerful cities, and they emerge as such in our analysis. Even at the "top," however, there are some interesting findings. Tokyo emerges as being considerably more powerful than it is typically described. Paris, seen as only an important "national" city by Friedmann (1995), emerges as a city of the first rank. Third, we find that the ranking of cities that emerges from our network analysis does not completely overlap with the rankings proposed by Friedmann (1995) and Beaverstock et al. (1999). A considerable proportion of the cities that they identify as "world cities" do not emerge as such in our analysis. In their place, we find a good number of cities that have been 


\section{World City System}

heretofore overlooked in the literature, a finding that we attribute to a tendency to conflate prestige and power. Finally, we find that the most powerful cities are also the most prestigious, indicating the operation of deference in the world city system.

Using regular equivalence blockmodeling techniques to generalize about the structure of the world city system, we find that the world city system comes close to approximating an idealized core/periphery structure (Borgatti and Everett 1999). This is a system in which blocks in the core are adjacent to each other and to some peripheral blocks, whereas blocks in the periphery are disconnected from one another. In the main, the "core" of the world city system is made up of seven blocks of cities that occupy a primary position in the network, that is, highly cliquish groups of cities that are involved in high levels of relations with outsiders (Marsden 1989). The most active of these active blocks in the world city system is the regularly equivalent set formed by the four cities identified as especially powerful and prestigious in the centrality analysis-London, New York, Paris, and Tokyo. These four cities send roughly $37 \%$ of the ties that are sent and receive about $15 \%$ of the ties that are received. The "periphery" of the world city system is composed largely of the 17 blocks that occupy the isolate position in the network, that is, internally disconnected groups of cities that play a passive role in the system. The largest of these, the Ålborg block, contains more than $40 \%$ of the cities in the system yet receives just $7 \%$ of the ties that are received and effectively sends no ties to other blocks or to others within the Ålborg block. As illustrated in figure 3 , the blockmodeled city system bears a very strong resemblance to the maximally centralized "star."

Our exploration of the question of the degree to which the position of cities in the contemporary world city system cuts across the traditional divides in the world system lends support to the position taken three decades ago by Stephen Hymer (1972). While there is certainly less than a one-to-one matching of cities onto nation-states in the world system, the ranking of cities on various measures of power and prestige and the position that such cities occupy in the city system is nonetheless significantly ordered by the world system position of the countries in which they are located. Moreover, it is ordered in a fashion that is consistent with the idea that cities located in core countries will, on average, be more powerful and prestigious and occupy a more active position than cities located in noncore countries. We find little evidence for the new geography of centrality and marginality discussed by scholars such as Friedmann (1986) and Sassen (2001). If the world city system does indeed undergird the structure of the world system and reproduce the core/periphery hierarchy in the interstate system (Smith and Timberlake 1995a), these results suggest that claims that the geography of the world system 
American Journal of Sociology

is in the midst of dramatic and fundamental alteration may also be overdrawn.

In this paper we have taken a step toward mapping the contemporary world city system. While we believe that we have made some progress in this regard, there are at least three limitations to the present analysis that are important to note. First, and most generally, the system that we describe in this paper, the hierarchy and structure that we observe, should be compared with data that allow for more culturally, socially, and politically informed senses of the power of cities. Given the paucity of relational data on these dimensions of the world city system, future researchers could explore ways of combining "traditional" data on the attributes of cities with our relational data. We are currently exploring such a possibility (Alderson and Beckfield 2002). Second, Friedmann and Sassen's arguments regarding the consequences of globalization for the world city system are fundamentally arguments about change. They imply that there was once a close correspondence between the map of the world city system and the map of the world system, but that this has been disrupted by global restructuring. The present analysis, of course, speaks only to the present fit of the maps, not to the degree of slippage between the two relative to some point in the past. By collecting the sort of data that we have collected for an earlier period, future research could test the longitudinal hypothesis that is implicit in these statements of the world city hypothesis. We are currently collecting such data. The introduction of a longitudinal component would also allow investigation of Smith and Timberlake's argument regarding the link between the structure of the urban hierarchy and the world system. Are the two actually tightly linked? Or are the processes that generate the global urban hierarchy largely independent of those that generate a core/periphery structure in the interstate system? Finally, the ultimate aim of all world city research is, of course, to say something meaningful about the changing fortunes of cities and their residents. Future researchers could combine our measures of power, privilege, and position with, for instance, readily available data at the SMSA (United States) or NUTS 5 (European Union) levels. With such data they could rigorously assess arguments in the world cities literature about how the position of cities in the global urban network affects their fate-the ultimate test of the utility of the new way of thinking on cities initiated by Friedmann (1986).

\section{REFERENCES}

Abbott, Carl. 1997. "The International City Hypothesis: An Approach to the Recent History of U.S. Cities." Journal of Urban History 24:28-52.

Alderson, Arthur S., and Jason Beckfield. 2002. "Globalization and the Centralization 


\section{World City System}

of Power in the World City System: A Neural Network Approach.” Paper presented at the XVI World Congress of Sociology, Brisbane, Australia, July.

Arrighi, Giovanni. 1994. The Long Twentieth Century: Money, Power, and the Origins of Our Time. London: Verso.

Beaverstock, J. V., P. J. Taylor, and R. G. Smith. 1999. "A Roster of World Cities." Cities 16:445-58.

Blanton, Robert G. 1999. "Trading Blocs and the Capitalist World-Economy: Insights and Evidence." Sociological Inquiry 69:187-215.

Bollen, Kenneth A. 1983. "World System Position, Dependency, and Democracy: The Cross-National Evidence." American Sociological Review 48:468-79.

Bollen, Kenneth A., and Stephen J. Appold. 1993. "National Industrial Structure and the Global System." American Sociological Review 58:283-301.

Borgatti, Steven P., and Martin G. Everett. 1999. "Models of Core/Periphery Structures." Social Networks 21:375-95.

Borgatti, Steven P., Martin G. Everett, and Linton C. Freeman. 2002. UCINET for Windows: Software for Social Network Analysis. Cambridge, Mass.: Analytic Technologies.

Burt, Ronald S. 1976. "Positions in Networks." Social Forces 55:93-122.

Castells, Manuel. 1972. La Question urbaine. Paris: Maspero.

Chandler, Alfred D., and Fritz Redlich. 1961. "Recent Developments in American Business Administration and Their Conceptualization." Business History Review $35: 1-27$.

Chase-Dunn, Christopher. 1985. "The System of World Cities: A.D. 800-1975." Pp. 269-92 in Urbanization in the World-Economy, edited by Michael Timberlake. New York: Academic Press.

Chase-Dunn, Christopher, and Peter Grimes. 1995. "World-Systems Analysis." Annual Review of Sociology 21:387-417.

Chase-Dunn, Christopher, and Susan Manning. 1999. "City Systems and WorldSystems: Four Millennia of City Growth and Decline.” Manuscript. Johns Hopkins University.

Cohen, R. B. 1981. "The New International Division of Labor, Multinational Corporations, and Urban Hierarchy." Pp. 287-315 in Urbanization and Urban Planning in Capitalist Society, edited by Michael Dear and Allen Scott. New York: Methuen.

Cohen, Saul B., ed. 2002. The Columbia Gazetteer of the World Online. New York: Columbia University Press.

Duncan, Otis D., W. Richard Scott, Stanley Lieberson, Beverly Duncan, and Harold Winsborough. 1960. Metropolis and Region. Baltimore: Johns Hopkins University Press.

Eades, Peter. 1984. "A Heuristic for Graph Drawing." Congressus Numerantium 42: 149-60.

Faust, Katherine. 1988. "Comparison of Methods for Positional Analysis: Structural and General Equivalences." Social Networks 10:313-41.

Fortune. 2000. "The Global 500 List." July 24, pp. 227-34, F-1-F-24.

Frank, Andre Gunder. 1998. Reorient: Global Economy in the Asian Age. Berkeley and Los Angeles: University of California Press.

Freeman, Linton. 1979. "Centrality in Social Networks I: Conceptual Clarification." Social Networks 1:215-39.

Friedmann, John. 1986. "The World City Hypothesis." Development and Change 17: 69-84.

- 1995. "Where We Stand: A Decade of World City Research." Pp. 21-47 in World Cities in a World-System, edited by Paul L. Knox and Peter J. Taylor. New York: Cambridge University Press. 


\section{American Journal of Sociology}

Fruchterman, Thomas M. J., and Edward M. Reingold. 1991. "Graph Drawing by Force-Directed Placement." Software-Practice and Experience 21:1129-64.

Godfrey, B. J., and Y. Zhou. 1999. "Ranking World Cities: Multinational Corporations and the Global Urban Hierarchy." Urban Geography 20:268-81.

Good, Phillip. 2000. Permutation Tests: A Practical Guide to Resampling Methods for Testing Hypotheses. New York: Springer-Verlag.

Granovetter, Mark. 1973. "The Strength of Weak Ties.” American Journal of Sociology 78:1360-80.

Guiffre, Katherine. 1999. "Sandpiles of Opportunity: Success in the Art World." Social Forces 77:815-32.

Harvey, David. 1973. Social Justice and the City. London: Edward Arnold.

Hawley, Amos. 1950. Human Ecology. New York: Ronald Press.

Hymer, Stephen. 1972. "The Multinational Corporation and the Law of Uneven Development." Pp. 113-40 in Economics and World Order, edited by Jagdish N. Bhagwati. New York: Macmillan.

Junne, Gerd. 1999. "Global Cooperation or Rival Trade Blocs?" Pp. 99-118 in The Future of Global Conflict, edited by Volker Bornschier and Christopher Chase-Dunn. London: Sage.

Knox, Paul L. 1996. "Globalization and the World City Hypothesis." Scottish Geographical Magazine 112:124-26.

Knox, Paul L., and Peter J. Taylor. 1995. World Cities in a World-System. New York: Cambridge University Press.

Lyons, Donald, and Scott Salmon. 1995. "World Cities, Multinational Corporations and Urban Hierarchy: The Case of the United States." Pp. 98-114 in World Cities in a World-System, edited by Paul L. Knox and Peter J. Taylor. New York: Cambridge University Press.

Marsden, Peter V. 1989. "Methods for the Characterization of Role Structures in Network Analysis." Pp. 489-530 in Research Methods in Social Network Analysis, edited by Linton C. Freeman et al. Fairfax, Va.: George Mason University Press.

Meijer, M. 1993. "Growth and Decline of European Cities: Changing Positions of Cities in Europe." Urban Studies 30:981-90.

Meyer, David R. 1986. "The World System of Cities: Relations between International Financial Metropolises and South American Cities." Social Forces 64:553-81.

National Geographic Society. 1996. National Geographic Atlas of the World, 6th ed. Washington, D.C.: National Geographic Society.

National Register. 2000. Directory of Corporate Affiliations. Skokie, Ill.: National Register.

Nemeth, Roger, and David A. Smith. 1985. "International Trade and World-System Structure: A Multiple Network Analysis." Review: A Journal of the Fernand Bruadel Center 8:517-60.

Padgett, John F., and Christopher K. Ansell. 1993. "Robust Action and the Rise of the Medici." American Journal of Sociology 98:1259-1319.

Ross, Christopher. 1987. "Organizational Dimensions of Metropolitan Dominance: Prominence in the Network of Corporate Control, 1955-1975." American Sociological Review 52:258-67.

- 1992. The Urban System and Networks of Corporate Control. Greenwich, Conn.: JAI Press.

Sassen, Saskia. 1994. Cities in a World Economy. Thousand Oaks, Calif.: Pine Forge Press.

- 2001. The Global City: New York, London, Tokyo. 2d ed. Princeton, N.J.: Princeton University Press.

Shin, Kyoung-Ho, and Michael Timberlake. 2000. "World Cities in Asia: Cliques, Centrality and Connectedness." Urban Studies 37: 2257-85.

Short, J. R., Y. Kim, M. Kuus, and H. Wells. 1996. "The Dirty Little Secret of World 


\section{World City System}

Cities Research: Data Problems in Comparative Analysis." International Journal of Urban and Regional Research 20:697-717.

Smith, David A., and Michael Timberlake. 1993. "World Cities: A Political Economy/ Global Network Approach." Research in Urban Sociology 3:181-207.

. 1995a. "Cities in Global Matrices: Toward Mapping the World-System's CitySystem." Pp. 79-97 in World Cities in a World-System, edited by Paul L. Knox and Peter J. Taylor. New York: Cambridge University Press. 1995b. "Conceptualising and Mapping the Structure of the World's City System." Urban Studies 32:287-302.

- 2001. "World City Networks and Hierarchies, 1977-1997." American Behavioral Scientist 44:1656-78.

2002. "Hierarchies of Dominance among World Cities: A Network Approach." Pp. 117-41 in Global Networks, Linked Cities, edited by Saskia Sassen. New York: Routledge.

Smith, David A., and Douglas R. White. 1992. "Structure and Dynamics of the Global Economy: Network Analysis of International Trade 1965-1980." Social Forces 70: 857-93.

Snyder, David, and Edward Kick. 1979. "Structural Position in the World System and Economic Growth, 1955-1970: A Multiple-Network Analysis of Transnational Interactions." American Journal of Sociology 84:1096-1126.

Stata Corporation. 2002. Stata/SE 7.0. College Station, Texas: Stata Corporation.

Sudjik, Deyan. 1992. The 100 Mile City. San Diego, Calif.: Harcourt Brace.

Taylor, Peter J., D. R. F. Walker, and J. V. Beaverstock. 2002. "Firms and Their Global Service Networks." Pp. 93-115 in Global Networks, Linked Cities, edited by Saskia Sassen. New York: Routledge.

Wallerstein, Immanuel. 1974. The Modern World-System. New York: Academic Press. Wasserman, Stanley, and Katherine Faust. 1994. Social Network Analysis: Methods and Applications. Cambridge: Cambridge University Press.

White, Douglas R. 1984. "REGE: A Regular Graph Equivalence Algorithm for Computing Role Distances Prior to Block Modelling.” Manuscript. University of California, Irvine.

White, Douglas R., and Karl P. Reitz. 1983. "Graph and Semi-group Homomorphisms on Networks of Relations." Social Networks 6:193-235.

—. 1985. "Measuring Role Distance: Structural, Regular, and Relational Equivalence." Manuscript. University of California, Irvine.

White, Harrison C., Scott A. Boorman, and Ronald L. Breiger. 1976. "Social Structure from Multiple Networks I: Blockmodels of Roles and Positions." American Journal of Sociology 81:730-80.

World Bank. 2002. World Development Indicators [CD-ROM]. Washington, D.C.: World Bank. 